\title{
Diet composition of carnivorous fishes from coral reef lagoons of New Caledonia
}

\author{
Michel Kulbicki ${ }^{1, a}$, Yves-Marie Bozec ${ }^{1,2}$, Pierre Labrosse ${ }^{3}$, Yves Letourneur ${ }^{3}$, \\ Gérard Mou-Tham ${ }^{1}$ and Laurent Wantiez ${ }^{4}$ \\ 1 UR-CoRéUs, Institut de Recherche pour le Développement (IRD), Université de Perpignan, 66860 Perpignan Cedex, France \\ 2 Département Halieutique UPR Mesh, Agrocampus Rennes, 65 rue de St-Brieuc, CS 84215, 35042 Rennes Cedex, France \\ 3 Université de la Méditerranée, Centre d'Océanologie de Marseille, Campus de Luminy, Case 901, 13288 Marseille Cedex 09, France \\ ${ }^{4}$ Université de Nouvelle-Calédonie, BP 4477, 98847 Nouméa, New Caledonia
}

Received 22 March 2005; Accepted 7 September 2005

\begin{abstract}
A total of 212 carnivorous coastal fish species from New Caledonia, represented by 7335 individuals, were analysed for their diet. Fifty two prey items were identified and later grouped into broader taxonomic categories refered as "prey types". For each fish species 6 biological traits were defined: maximum adult size, major biotope, schooling behaviour, home range, nycthemeral behaviour, degree of crypticity. A general linear model was fit to the diet data taking into account these traits, and depth of capture and fish family. This model was applied to the average number of prey types/stomach and to the volume of 5 prey types: nekton, crustaceans, molluscs, echinoderms, worms. A second analysis was performed on the effect of observed size on diet composition, taking into account these traits and taxonomy. This analysis was restricted to species with at least five individuals, representing 113 species from 33 families. More detailed information is given for the three major families, Serranidae, Lutjanidae and Lethrinidae and intra-family variations are illustrated for Lethrinidae. All the factors tested had significant effects on diet, fish size and taxonomy being the two major factors. The five prey types analysed in detail displayed marked differences according to the factors studied. In particular nekton increased in importance with fish size, whereas crustaceans decreased and molluscs presented a dome shaped relationship. Nekton and crustaceans made the bulk of the diet of most species, with molluscs being at times important. Echinoderms and worms were never a major food item and were eaten only by a restricted range of species.
\end{abstract}

Key words: Coral reefs / Fish diet / Trophic level / Indian Ocean

Résumé - Régime alimentaire de poissons carnivores des récifs coralliens de Nouvelle Calédonie. Un ensemble de 212 espèces de poissons carnivores côtiers de Nouvelle Calédonie, représentées par 7335 spécimens, ont été analysés pour étudier leur régime alimentaire. Cinquante-deux types de proies ont été identifiées et regroupées par la suite dans des catégories plus vastes ou «type de proies ». Pour chaque espèce, six caractéristiques biologiques ont été définies : taille adulte maximale, principal biotope, grégarité, domaine vital, comportement nycthéméral, niveau de crypticité. Un modèle linéaire général a été ajusté à ces données, en prenant en compte ces caractéristiques ainsi que la profondeur de capture et la famille. Ce modèle est appliqué au nombre moyen de proies par estomac ainsi qu' au volume de cinq types de proies : necton, crustacés, mollusques, échinodermes et vers. Une seconde analyse porte sur les effets de la taille observée sur la composition de l'alimentation, prenant en compte ces caractéristiques vitales et la taxonomie; cette analyse est restreinte aux espèces comportant au moins 5 spécimens, ce qui représente 113 espèces provenant de 33 familles. Une information plus détaillée est fournie pour les trois familles principales : Serranidae, Lutjanidae et Lethrinidae et les variations au sein d'une même famille sont illustrées pour les Lethrinidae. Tous les facteurs testés ont un effet significatif sur l'alimentation; la taille et la taxonomie étant les deux facteurs principaux. Les cinq types de proies analysés en détail présentent des différences importantes en fonction des facteurs étudiés. En particulier, le necton augmente en importance avec la taille des poissons, alors que les crustacés ont une tendance inverse, et les mollusques présentent une courbe en cloche. Necton et crustacés constituent l'essentiel des proies pour la plupart des espèces, les mollusques étant parfois importants. Les échinodermes et les vers ne constituent jamais un aliment majeur et ne sont consommés que par un nombre restreint d'espèces.

\footnotetext{
a Corresponding author: michel.kulbicki@univ-perp.fr
} 


\section{Introduction}

The functioning of fish assemblages depends in great part on the trophic status of the species within the assemblages. The diet of most fishes will change with a number of factors, either intrinsic (e.g. size, behaviour, taxonomy) or extrinsic (e.g. biotope, region). Information on the diet of fishes is important to understand the basic functioning of fish assemblages and is widely used for ecological work and modelling and is becoming an increasingly important component in ecologically based management. The downward shift of the trophic composition of the catch world wide, which was formely dominated by large carnivorous species (Pauly et al. 1998), has also attracted attention towards the trophic status of species. In areas with very high fish diversity, such as the South Pacific which hosts over 2000 species of coastal fishes, the level of the information on the diets of fishes is often low and difficult to access.

The present article intends to yield information on the diet of large carnivorous fish species of New Caledonia, with attention drawn on some of the major factors affecting these diets. Despite the descriptive nature of this information, we feel it will be usefull because:

1- Most coastal fish species have a very wide geographical range in the Indo-Pacific, e.g. more than $50 \%$ of the species observed in New Caledonia are found from the Reunion island (western Indian Ocean) all the way to Polynesia (central Pacific), spanning over $15000 \mathrm{~km}$ (Letourneur et al. 1997). This applies in particular to the large carnivorous species which are dominated by a restricted number of families, four of them making the bulk of the commercial catch: Lethrinidae, Lutjanidae, Serranidae and Carangidae. These four families have a very low endemism and all the species found in New Caledonia occur in most of the South Pacific islands (Carpenter and Niem 2000).

2- In the tropical Pacific, the diversity of shallow water fish communities is dominated by carnivorous species, the relative importance of this trophic category increasing significantly (Kulbicki et al. 2004) from West (Great Barrier Reef) to East (Polynesia). More specifically, in the lagoon of New Caledonia carnivores dominate softbottoms (Wantiez 1994), algae and sea-grass beds (Rossier and Kulbicki 2000), mangroves (Thollot et al. 1999) and are dominant on reefs in terms of diversity and biomass (Kulbicki 1997).

3- Diet information for these carnivorous reef fish species is found in an array of articles, but usually the number of specimens analysed remains low for each species, and most of this literature is difficult to obtain and often old (based on a review of 286 articles on the diet of reef fishes, some of the most informative literature on this matter is: Hiatt and Strasburg 1960; Hobson 1974; Harmelin-Vivien 1979; Blaber 1980; Randall 1980; Sano et al. 1984; Norris 1985; Parrish 1987; Abu Khair et al. 1990; Salini et al. 1994; Blaber et al. 1990; Nakamura et al. 2003). This study covers a wide spectrum of species, as diet information could be retrieved for 7335 carnivorous fish representing 212 species

4- Most species display some plasticity in their diet, fish being rather opportunistic feeders (e.g. Walker 1978;
Harmelin-Vivien 1981; Harmelin-Vivien et al. 1989; Salini et al. 1994). Many factors play a role in this plasticity, such as size (e.g. Harmelin-Vivien et al. 1989; Kingsford 1992), season (e.g. Kingsford 1992; Salini et al. 1994) or region (Shpigel and Fishelson 1989). However, many other factors play a role and most have been so far poorly documented. The present article intends to investigate the effects of some intrinsic factors (size, schooling behaviour, home range, nycthemeral activity, crypticity and taxonomy) and extrinsic factors (biotope and depth).

5- Detailed diet information is useful to tropho-dynamic models (Cury et al. 2002; Pauly et al. 2002), to estimate trophic levels (Froese and Pauly 2000; Stergiou and Karpouzi 2002) which may enter in the composition of ecosystem indicators (Pauly et al. 1998 2001; Pinnegar et al. 2002; Laurans et al. 2004; Bozec et al. 2005; Gascuel et al. 2005).

\section{Material and methods}

\subsection{Study area and fish collections}

All the fish studied were caught in four areas of New Caledonia (Fig. 1): Chesterfield Islands, Uvea Atoll, the Southwest lagoon (South Province) and the East, West and North lagoons (North Province). The study areas cover various biota (coral reefs, lagoonal sandy areas, soft-bottoms, bays, estuaries, mangroves). Fish were caught during several scientific and monitoring programs led by IRD between 1985 and 1997. A wide array of methods was used to catch these fish (hand lines, longlines, trawls, gill nets, rotenone). The weight and length were recorded for each specimen. Fish length was taken as fork length, except for species with a rounded tail for which total length was measured. Fish were usually examined fresh but in some cases, when dissection in the field could not be performed, the fish were frozen or preserved in alcohol for later study.

\subsection{Stomach analysis}

Each prey item was identified to the genus, family or order level. This resulted in a total of 52 prey items which were later allocated to broader taxonomic groups, hereafter refered to as prey types. The percentage volumetric contribution $(\% \mathrm{~V})$ made by each prey type to the total volume of the stomach contents was estimated for each individual. Only the four most important prey types (in \% V) in a stomach were noted, as in most cases, this allowed to include all the stomach content.

\subsection{Data analysis}

Many factors play a role in the diet of these carnivorous fishes. These factors are not independent, and it would be rapidly tedious to analyse each factor separately. For this reason, we first performed a general analysis in which as many factors as possible were analysed in the same statistical model, then we focused on two major aspects: size and taxonomy. 


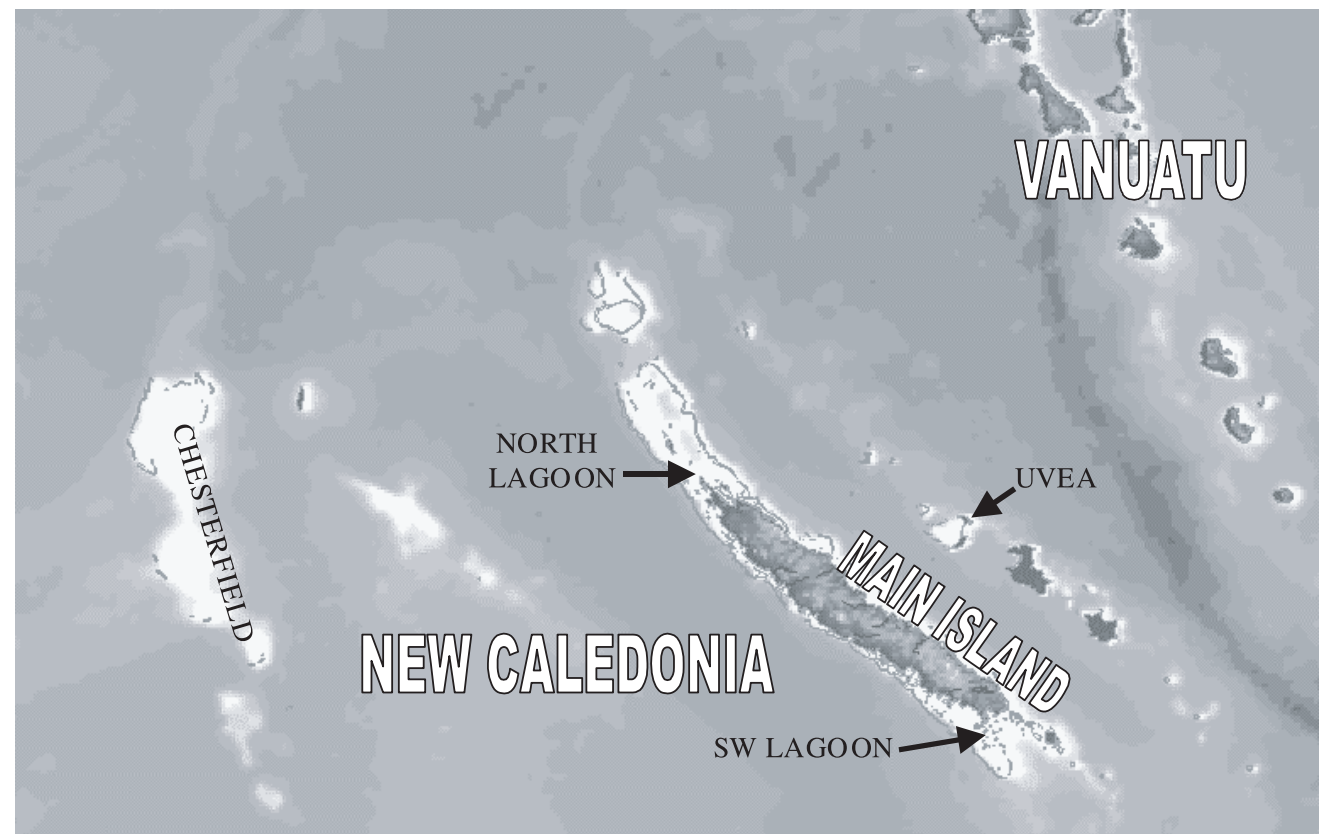

Fig. 1. Location of the major sampling areas of this study (extracted from Reef Base).

\subsubsection{General model}

Six characteristics were attributed to each species: its maximum adult size, its major biotope, its schooling behaviour, its degree of crypticity, its home range type and its nycthemeral behaviour. Adult size is the largest size known to occur in New Caledonia. Only four biotopes were kept: reef, soft bottom, near shore (mangroves, estuaries and coastal areas) and pelagic. Species were attributed several biotopes if needed (e.g. most Lethrinidae frequent both reef and soft bottom). Depth of catch was also taken into account. Species were distributed amongst five schooling types: solitary, paired, small schools (2-20 fish on average), medium size schools (20-50 fish), large schools ( $>50$ fish). Species were classified as very cryptic, cryptic or non cryptic. Species were classified as having a small, medium or large home range. Species were also classified as either diurnal, nocturnal or constantly active. Prey types were restricted to 10 categories (Table 1).

To determine which factors were significant on the types or numbers of prey, a multiple regression was performed. The dependent variable was either prey volume or number of prey types averaged per species (volume or numbers per fish would have biased results in favor of the most sampled species). The independent variables were family, biotope, depth, adult size, crypticity and schooling behaviour. As families were coded qualitatively and biotopes, crypticity, nycthemeral activity and schooling behaviour were coded as present/absent, a GLM procedure was chosen to perform the analyses (Muller and Fetterman 2003). Interactions between factors were not included in the model as there were too many empty cells. The models may be written as follows:

Prey volume (or Number of prey types) $=a_{0}+a_{1}$ Depth + $a_{2}$ Biotope $+a_{3}$ Family $+a_{4}$ Size (adult) $+a_{5}$ SchoolSize $+a_{6}$ HomeRange $+a_{7}$ DielActivity $+a_{8}$ Crypticity $+\varepsilon$.
Table 1. Prey groups definition for the size-based analysis (6 prey groups) the taxonomy-based analysis (10 prey groups).

\begin{tabular}{|c|c|c|}
\hline $\begin{array}{l}\text { Size-based } \\
\text { analysis }\end{array}$ & $\begin{array}{l}\text { General model and } \\
\text { Taxonomy-based } \\
\text { analyses }\end{array}$ & $\begin{array}{l}\text { Major } \\
\text { Components }\end{array}$ \\
\hline Fishes & Fishes & Fishes \\
\hline \multirow[t]{4}{*}{ Crustaceans } & Crabs & Crabs \\
\hline & Shrimps & Shrimps \\
\hline & Other crustaceans & Mantis shrimps \\
\hline & & Undet. crustaceans \\
\hline \multirow[t]{3}{*}{ Molluscs } & Bivalves & Bivalves \\
\hline & Gastropods & Gastropods \\
\hline & Undet. molluscs & Undet. molluses \\
\hline \multirow[t]{6}{*}{ Echinoderms } & Echinoderms & Brittle stars \\
\hline & & Sea stars \\
\hline & & Crinoids \\
\hline & & Sea urchins \\
\hline & & Sea cucumbers \\
\hline & & Undet. echinoderms \\
\hline Worms & Worms & $\begin{array}{l}\text { Worms (polychaetes, } \\
\text { etc.) }\end{array}$ \\
\hline \multirow[t]{8}{*}{ Others } & Others & Squids/cuttlefish \\
\hline & & Octopus \\
\hline & & Corals \\
\hline & & Jelly fish \\
\hline & & Nudibranchs \\
\hline & & Sponges \\
\hline & & Benthic algae \\
\hline & & Planktonic crustaceans \\
\hline
\end{tabular}

\subsubsection{Size-based (observed size) analysis of fish diets}

Size-related changes in the diet compositions were analysed, using a limited number of size classes, in order to 
Table 2. Average diet of carnivorous Caledonian reef fishes, expressed as mean percentages of the relative volume occupied by 10 prey types in the fish diets. Results are presented by fish family, with the number of species sampled in brackets; n: the number of specimens analysed (stomachs); -: value lower than 1. Ech: echinoderms; Wo: worms; Oth: others; Cr: crabs; Shr: shrimps; Biv: bivalves; Gas: gasteropods; Un: undetermined molluscs.

\begin{tabular}{|c|c|c|c|c|c|c|c|c|c|c|c|}
\hline \multirow{3}{*}{ Family } & & \multirow[t]{2}{*}{ Fish } & \multicolumn{3}{|c|}{ Crustaceans } & \multicolumn{3}{|c|}{ Molluscs } & \multirow[t]{2}{*}{ Ech } & \multirow[t]{2}{*}{ Wo } & \multirow[t]{2}{*}{ Oth } \\
\hline & & & $\mathrm{Cr}$ & Shr & Oth & Biv & Gas & Un & & & \\
\hline & $n$ & & & & & & & & & & \\
\hline Synodontidae (3) & 254 & 97 & - & 3 & & & & & & & \\
\hline Sphyraenidae (5) & 109 & 95 & & - & 1 & 1 & & & & & $3^{(1)}$ \\
\hline Carangidae (10) & 190 & 72 & 13 & 9 & 3 & & & & - & & $3^{(2)}$ \\
\hline Serranidae (14) & 432 & 48 & 33 & 9 & 5 & 1 & - & 1 & 1 & - & 2 \\
\hline Bothidae (3) & 35 & 36 & 12 & 11 & 13 & & & & & 28 & \\
\hline Lutjanidae (14) & 1100 & 34 & 32 & 12 & 9 & 1 & 1 & 3 & 1 & 2 & $4^{(1,3,4)}$ \\
\hline Lethrinidae (16) & 2670 & 16 & 23 & 2 & 6 & 17 & 2 & 12 & 10 & 8 & $4^{(1,4,3)}$ \\
\hline Nemipteridae (3) & 615 & 13 & 31 & 12 & 6 & 7 & 1 & 3 & 1 & 23 & 2 \\
\hline Holocentridae (3) & 126 & 12 & 55 & 23 & 5 & 1 & & - & & 1 & 2 \\
\hline Mullidae (9) & 696 & 6 & 29 & 31 & 12 & 6 & - & 2 & 3 & 10 & 1 \\
\hline Haemulidae (5) & 271 & 5 & 46 & 7 & 7 & 8 & 7 & 9 & 4 & 5 & 2 \\
\hline Tetraodontidae (4) & 46 & 4 & 23 & 2 & 3 & 26 & 11 & 4 & 11 & & $16^{(5,6)}$ \\
\hline Balistidae (3) & 64 & 3 & 22 & 1 & 10 & 22 & & 30 & 10 & 1 & $11^{(6)}$ \\
\hline
\end{tabular}

${ }^{(1)}$ Squids/cuttlefish, ${ }^{(2)}$ planktonic crustaceans, ${ }^{(3)}$ octopi, ${ }^{(4)}$ nudibranchs, ${ }^{(5)}$ sponges, ${ }^{(6)}$ corals.

produce a sufficient number of dietary samples. Hence, body size of each fish specimen was rounded up or down to the nearest $10 \mathrm{~cm}$ (e.g. 35-44 cm became $40 \mathrm{~cm}$ ), except for fishes greater than $70 \mathrm{~cm}$ which were grouped into the $70-\mathrm{cm}$ class.

In a first step, prey types were grouped into 6 major categories (Table 1). Then, the mean volumetric contribution $(\% \mathrm{~V})$ of these 6 prey categories to the total stomach content was calculated for each species for all size classes. Only species, with at least five stomach contents, were selected in a given size class. In a second step, a mean diet composition was estimated for each size class by averaging all species within the size class.

The same approach was adopted for the three most sampled fish families, i.e., Lethrinidae, Lutjanidae and Serranidae, which diet compositions were first averaged by species, and then averaged by size class.

To analyse the effects of observed size on prey volume $V$, a linear model taking into account species and observed size groups was performed according to the model:

$$
V=a_{0}+a_{1} \text { Species }+a_{2} \text { Size }+\varepsilon .
$$

\subsubsection{Taxonomical analysis}

Fish species represented by five or more stomach contents were selected for the taxonomy-based analysis at the species level. First, prey types were grouped into 10 major prey types (Table 1). The diet composition was then estimated for each species as the mean percentage volumetric contribution for each of these 10 prey types.

In a second step, the diet compositions of several fish families were estimated by averaging the mean diet of the various species in a family, in order to avoid biased results due to the most sampled species. Only fish families with three or more species were selected.

\section{Results}

In our data base, 7335 specimens of carnivorous species had a full stomach. This represented 212 species. The analysis of fish species represented by five or more stomach contents resulted in a mean diet composition for 113 species from 33 families which is presented in Appendix I. The mean diet composition for the selected fish families (three or more species) is presented in Table 2.

\subsection{General model}

All the factors included in the model had a significant effect on either the number of prey types or on the volume of these prey types (Table 3 ).

\subsubsection{Number of prey types}

The only set of factor which had no significant effect on the number of prey types was crypticity (Table 3 ).

There is an increase in the number of prey types as one goes from the least complex biotope (pelagic) to the most complex (reef). There is a slight increase in the number of prey types with home range, mobile species having more prey types than sedentary ones. The number of prey types tends to decrease with school size, however, solitary species have also low number of prey types. Species which are active at night have larger numbers of prey types (Table 4).

\subsubsection{Prey volumes}

\section{General}

The most important prey items were in decreasing order fish, crabs, shrimps, bivalves, and worms (Table 4), these five 
Table 3. Degree of significance of the tested factors in the general linear models (GLMs). Each column represents the results of one model. NS: not significant; *: $p<0.05 ; * *: p<0.01 ; * *: p<0.001$

\begin{tabular}{|c|c|c|c|c|c|c|c|}
\hline & & Nb Prey types & Nekton & Crustacean & Echinoderm & Mollusc & Worm \\
\hline & Intercept & $* * *$ & NS & NS & NS & ** & * \\
\hline Habitat \& & Depth & * & * & **** & $* *$ & $* * *$ & * \\
\hline \multirow[t]{4}{*}{ Biotope } & Reef & $* * *$ & $* * *$ & NS & NS & $* * *$ & $* * *$ \\
\hline & Soft-Bottom & $* * *$ & $* * *$ & $* *$ & NS & $* * *$ & $* * *$ \\
\hline & Nearshore & $* * *$ & $* * *$ & $* * *$ & NS & $* * *$ & * \\
\hline & Pelagic & NS & NS & NS & NS & NS & NS \\
\hline Family & & $* * *$ & $* * *$ & $* * *$ & $* * *$ & $* * *$ & $* * *$ \\
\hline Size (adult) & & $* * *$ & $* * *$ & **** & NS & ** & NS \\
\hline \multirow[t]{4}{*}{ Schooling } & Solitary & ** & $* * *$ & $* * *$ & $*$ & $* * *$ & $\overline{N S}$ \\
\hline & Paired & $* *$ & $* * *$ & NS & NS & * & NS \\
\hline & Small-S & NS & NS & $* *$ & $*$ & $*$ & NS \\
\hline & Medium-S & $* *$ & $*$ & $* * *$ & NS & $* * *$ & $* * *$ \\
\hline \multirow[t]{2}{*}{ Home range } & Short & $* *$ & NS & NS & * & $* * *$ & NS \\
\hline & Medium & $* * *$ & $* * *$ & $*$ & $*$ & $* * *$ & $* * *$ \\
\hline Nycthemeral & Constant & * & $* * *$ & NS & * & $* * *$ & * \\
\hline Activity & Day & ** & * & $* * *$ & NS & $* * *$ & $* * *$ \\
\hline Crypticity & Cryptic & $\mathrm{NS}$ & $*$ & $\mathrm{NS}$ & $\overline{N S}$ & $*$ & NS \\
\hline Level & Non-Cryptic & NS & NS & NS & NS & NS & NS \\
\hline
\end{tabular}

Table 4. Average diet composition (\%) according to Home range S: small; M: medium; L: large; School size Sol: solitary; P: paired; Sc: small school; MSc: medium size school; LSc: large size school; Nycthemeral activity Cst: constantly active; D: daytime active; N: nightime active; Crypticity NC: non cryptic; C: cryptic; VC: very cryptic; Biotope R: reef; SB: soft bottom; Ns: nearshore; H: pelagic.

\begin{tabular}{|c|c|c|c|c|c|c|c|c|c|c|c|c|c|c|c|c|c|c|c|}
\hline & \multicolumn{3}{|c|}{ Home Range } & \multicolumn{5}{|c|}{ School Size } & \multicolumn{3}{|c|}{ Nycthemeral } & \multicolumn{3}{|c|}{ Crypticity Level } & \multicolumn{4}{|c|}{ Biotope } & \multirow[t]{2}{*}{ Total } \\
\hline & S & M & $\mathrm{L}$ & Sol & $\mathrm{P}$ & Sc & MSc & $\mathrm{LSc}$ & Cst & D & $\mathrm{N}$ & $\mathrm{NC}$ & $\mathrm{C}$ & $\mathrm{VC}$ & $\mathrm{R}$ & SB & Ns & $\mathrm{H}$ & \\
\hline Nb-prey-types & 1.2 & 1.3 & 1.4 & 1.2 & 1.5 & 1.4 & 1.2 & 1.1 & 1.4 & 1.2 & 1.2 & 1.3 & 1.0 & 1.2 & 1.4 & 1.4 & 1.2 & 1.1 & 1.3 \\
\hline Nekton & 32.8 & 24.5 & 20.3 & 40.8 & 40.6 & 13.1 & 22.5 & 43.3 & 30.9 & 12.0 & 19.8 & 20.2 & 79 & 16 & 19 & 17.6 & 16.6 & 79.3 & 23.0 \\
\hline Crus & 54.8 & 36.0 & 40.5 & 32.4 & 52.0 & 39.4 & 45.6 & 38.6 & 27.2 & 46.6 & 55 & 40.2 & 18.1 & 79 & 37.8 & 36.5 & 65.3 & 17 & 39.8 \\
\hline Echino & 1.7 & 7.9 & 3.8 & 3.2 & 2.2 & 4.7 & 7.9 & 3.1 & 7.1 & 2.6 & 4.5 & 5.6 & 0 & 0.8 & 6.9 & 6.9 & 2.2 & 0.8 & 5.2 \\
\hline Molluscs & 8.3 & 25.6 & 24.7 & 20.0 & 1.7 & 31.8 & 16.7 & 6.8 & 30.3 & 21.6 & 14.6 & 25.3 & 0.9 & 3.2 & 31.5 & 28.7 & 10.3 & 0.9 & 23.8 \\
\hline Worms & 1.1 & 4.5 & 9.9 & 1.8 & 0.9 & 10.0 & 6.6 & 6.5 & 3.7 & 15.1 & 5.3 & 7.5 & 2.1 & 0.8 & 3.9 & 9.2 & 4.3 & 0 & 7.1 \\
\hline
\end{tabular}

items making $76.3 \%$ in occurrence and $82.5 \%$ in volume of all prey. Some food items are probably not eaten intentionally by carnivorous fishes. This could be the case of algae, coral and sponges. These items could be absorbed accidentally when a fish catches a prey living on these items. However, algae are mainly eaten by the smallest fish (Appendix II) which could be an indication that algae are actively eaten by some small specimens of otherwise carnivorous species.

\section{Biotope}

There are some major differences in prey types according to biotope (Table 4). The relative importance of nekton in the diet is very significantly affected by biotope type (Table 3 ) except for the pelagic biotope. Nekton follows a strong gradient from pelagic to reefs, being dominant for pelagic and near shore species, i.e. the biotopes with the least refuges for prey. Crustaceans are a major item for nearshore, soft bottoms and reefs and are the second most important item in pelagic fish stomachs (17\%, but far after nekton: $79 \%)$. Biotope is a significant factor in determining the level of crustacean in the diet for soft-bottom and mainly nearshore fishes (Table 3). Soft bottom and reef fish have nearly the same amount of crustaceans in their diets. Echinoderms are a minor diet item for all biotopes. Biotope is not a significant factor in determining the level of echinoderm in the diet of coastal fishes (Table 3), but depth was significant, echinoderms being found mostly in stomachs of fish caught in shallow areas. Molluscs followed an increasing gradient according to biotope complexity. Surprisingly, bivalves which are mainly sand dwelling organisms are more important in the diet of reef fishes than those from soft bottoms or near shore. Biotope is very significant in determining the level of molluscs in the diet of fish except for pelagic species (Table 3). Worms are associated to soft sediments and are mainly eaten by soft bottom and nearshore species, but reef and soft-bottoms are the two biotopes which are the most significant in determining the level of this item in the diets (Table 3).

\section{Home range}

The proportion of nekton in the diet tends to decrease with increasing home range (Table 4), worms displaying the opposite trend. The other food items do not show gradients linked to home range. Crustaceans are the major item of low and medium home range species, echinoderms are mainly eaten by medium home range species and molluscs are favored by medium to large home range species. Home range is especially significant in determining the level of molluscs in the diet (Table 3). 


\section{School size}

There is no gradient of prey volume with school size for any of the prey type studied (Table 4). School size plays however a very significant role in determining the level of molluscs and to a lesser extent nekton and crustacean (Table 3).

Species forming small or medium size schools tend to eat less nekton than other species. There is no specific trend for crustacean. Echinoderms are preferentially eaten by species forming medium size schools, this corresponding mainly to Lethrinidae. Molluscs are seldom eaten by pairing species or species forming large schools. Worms are more specifically eaten by species living in small schools (Table 4).

\section{Nycthemeral activity}

Nycthemeral activity has a very significant contribution to the level of molluscs, nekton, and worms, less significant contribution for crustaceans or echinoderms (Table 3). Fish which are constantly active eat more nekton, echinoderms and molluscs (Table 4). Nekton is much less favored by species which are active during the day only, these species having on the opposite the largest volume of worms in their diet and the lowest of echinoderms (Table 4). Night time active species are characterized by a higher proportion of crustaceans in their diet (Table 4).

\section{Crypticity}

This factor plays only a minor role in determining the volume of prey types (Table 3), being significant only for nekton and molluscs, though contrasted results occurred according to this variable (Table 4). In particular, non cryptic species are characterized by a much higher level of echinoderms, molluscs and worms in their diet, whereas cryptic species are characterized by the highest level of nekton (79\%) and $0 \%$ of echinoderm. Very cryptic species seem to specialize on crustaceans (79\% of their diet).

\subsection{Effect of size}

\subsubsection{Number of prey types (Table 5)}

The number of prey types tends to first increase with fish size then stabilises after $50 \mathrm{~cm}$ (Fig. 2). There are important variations from species to species. An analysis of all the relationships at the species level shows that only 25 species had a significant relationship between size and number of prey items (out of 122 species tested). The lack of correlation is due to the high dispersion of the values and also to the fact that some species (especially nekton feeders) tend to have only one item on average in their stomach (resulting in a nearly constant value of one item for all sizes). Fitting a parabolic curve resulted in only 22 significant relationships, but the fit was improved for only 9 species compared to a linear fit.

The increase of the number of prey types with size is more important for reef and soft-bottom species, and is nearly absent for pelagic species. The increase of prey types with size is accentuated by the increase in home range. This trend is little affected by school size, with however a steeper increase in

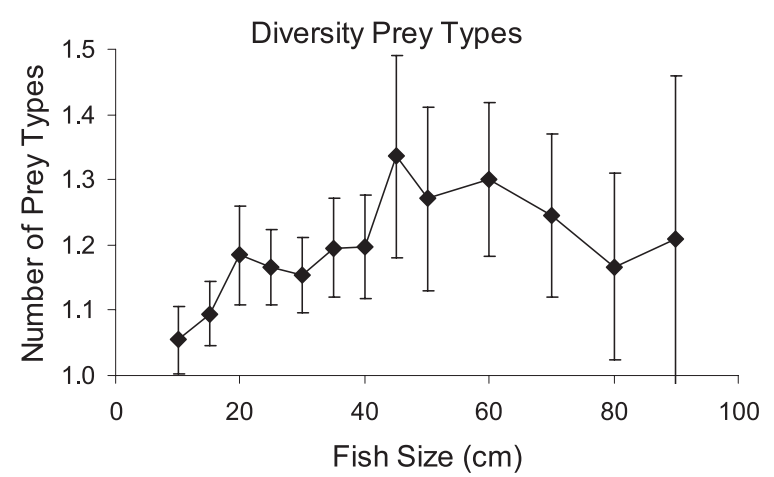

Fig. 2. Variations of the diversity of prey types with fish size. Data are estimated from species averages. The bars represent the $95 \%$ confidence intervals.

the number of prey types with size for species forming small schools. This relationship between size and prey types is significant for non cryptic species, but cryptic or very cryptic species do not show this trend. Nycthemeral activity has no influence on this relationship.

\subsubsection{Relative volume of prey (Table 5)}

\section{Nekton}

The relative number of species eating nekton increases with fish size and the relative volume of this item increases significantly with fish size (Fig. 3). The relationship between the importance of nekton in the diet and fish size varies according to most of the factors tested (Table 5). Nekton is the major prey items for the largest fish $(>80 \mathrm{~cm})$ in all biotopes. The difference with smaller size classes is striking, except for pelagic species for which there is a gradual increase of the importance of this item with size. If one excepts the largest sizes $(>80 \mathrm{~cm})$ there is not a constant pattern for the importance of nekton with size according to home range. Medium range species tend to display a decrease in the importance of nekton with size, opposite to species with small and large home ranges, for which nekton increases with size. Except for the species with medium size schools, school size has no effect on the relationship between the volume of nekton and fish size. Similarly only species active during the day display an increase in the importance of nekton with size. Cryptic species not only eat more nekton on average than other species, but this is true for all size classes.

\section{Crustaceans}

The relative number of species eating crustaceans tends to decrease with fish size and similarly the volume of this item tends to decrease in stomachs as fish size increases (Fig. 3). This decrease is more marked for reef species and soft bottom species, and is not observed for pelagic species. Species with a small home range tend to have very high levels of crustaceans in their stomachs when they are small $(<20 \mathrm{~cm})$. The decrease of crustaceans in stomach with fish size is however most marked for species with a large home range. School size does not have a clear influence on the relationship between 


\section{NEKTON}

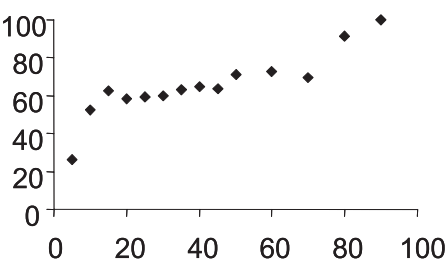

CRUSTACEANS
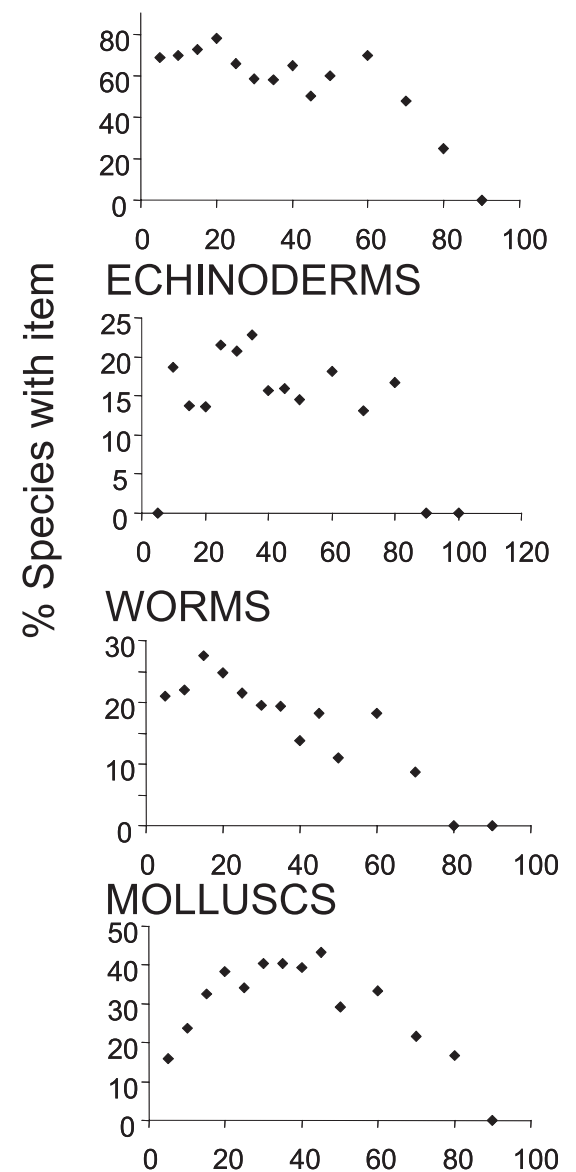
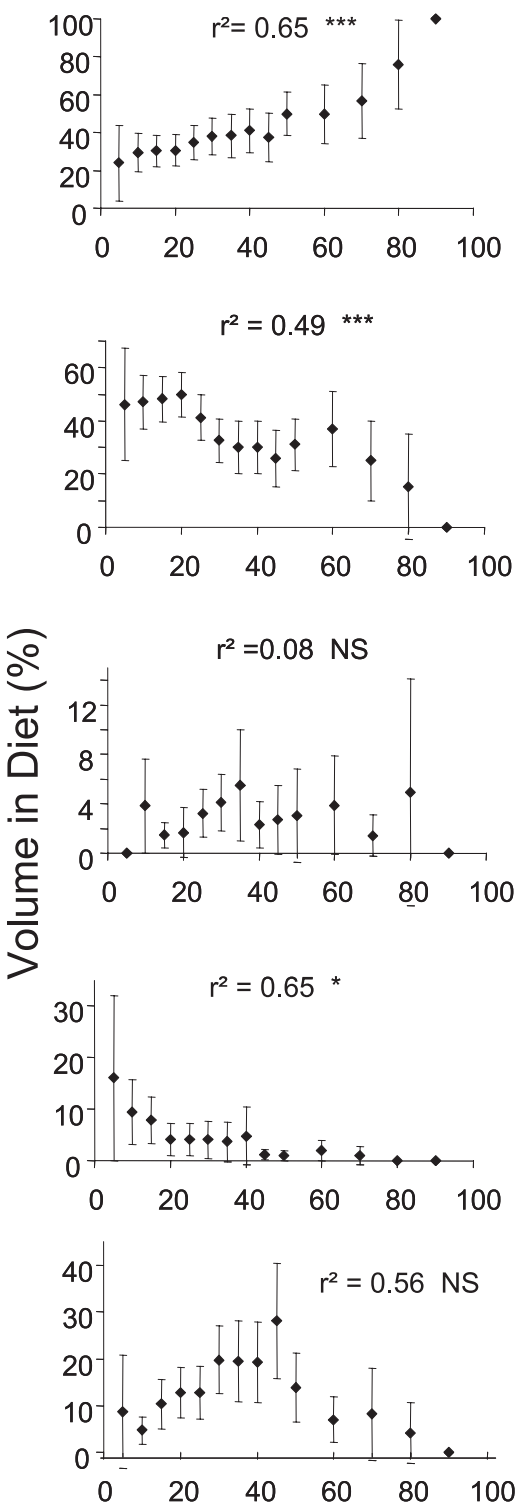

Size classes $(\mathrm{cm})$

Fig. 3. Variations of the proportion of species feeding on the major diet items according to fish size (graphs on left) and corresponding variations of the volume in the diet of the major items according to size (graphs on right). Each point is the average of all species within a size class $(5 \mathrm{~cm})$ (not the average of all individuals). $r^{2}$ : correlation coefficient for the whole model (Volume $=a_{0}+a_{1}$ Species $+a_{2}$ Size $+\varepsilon$ ), and the significance of the "Size" variable is given by: NS: not siginificant; *: $p<0.05 ; * *: p<0.01 ; * * *: p<0.001$.

crustacean volume in stomachs and fish size, however, the decrease is marked for both solitary species and species forming medium size schools. There is no relationship of crustacean with fish size for species which are constantly active and on the opposite this relationship is highly significant for species which are either active during day time or night time. Crypticity has no influence on this relationship.

\section{Echinoderms}

There is no pattern in the relative number of species eating echinoderms as size increases (Fig. 3), one notices however that echinoderms are not eaten by the largest fish. Similarly the volume of echinoderms shows no significant trend as fish size increases (Fig. 3). This lack of relationship is confirmed when analysing biotope, home range, school size, nycthemeral activity or crypticity (Table 5). One notices however, that the largest values are observed for medium size fishes $(20-80 \mathrm{~cm})$

\section{Worms}

The relative number of species eating worms tend to decrease with fish size and similarly there is a significant decrease in the importance of the volume of worms in the stomachs as fish size increases (Fig. 3). This decrease is only found for soft bottoms (Table 5), species eating worms in the 
Table 5. Average diet composition (\%) according to the combination of observed size with home range, school size, nycthemeral activity, level of crypticity and biotope. Numbers in italics represent cells for which there are less than 10 observations. Home range S: small; M: medium; L: large; School size Sol: solitary; P: paired; Sc: small school; MSc: medium size school; LSc: large size school; Nycthemeral activity Cst: constantly active; D: daytime active; N: nightime active; Crypticity NC: non cryptic; C: cryptic; VC: very cryptic; Biotope R: reef; SB: soft bottom; Ns: nearshore; H: pelagic.

\begin{tabular}{|c|c|c|c|c|c|c|c|c|c|c|c|c|c|c|c|c|c|c|c|}
\hline \multirow[t]{2}{*}{ Size } & \multicolumn{3}{|c|}{ Home-Range } & \multicolumn{5}{|c|}{ School Size } & \multicolumn{3}{|c|}{ Nycthemeral } & \multicolumn{3}{|c|}{ Crypticity Level } & \multicolumn{4}{|c|}{ Biotope } & \multirow[t]{2}{*}{ Total } \\
\hline & Sm & Med & $\mathrm{L}$ & Sol & $\mathrm{Pa}$ & Sc & M.Sc & LSc & Cst & $\mathrm{Dt}$ & $\mathrm{Nt}$ & $\mathrm{NC}$ & C & $\mathrm{VC}$ & $\mathrm{R}$ & SB & NS & $\mathrm{H}$ & \\
\hline \multicolumn{20}{|l|}{ Nb-prey-types } \\
\hline$<10 \mathrm{~cm}$ & 1.1 & 1.1 & 1.1 & 1.0 & & 1.1 & 1.1 & 1.0 & 1.1 & 1.1 & 1.1 & 1.1 & 1.1 & 1.22 & 1.06 & 1.08 & $I$ & 1 & 1.08 \\
\hline $10-20 \mathrm{~cm}$ & 1.2 & 1.1 & 1.1 & 1.1 & 1.2 & 1.2 & 1.2 & 1.1 & 1.1 & 1.1 & 1.2 & 1.2 & 1.0 & 1.28 & 1.17 & 1.15 & 1.13 & 1.03 & 1.15 \\
\hline $20-40 \mathrm{~cm}$ & 1.2 & 1.3 & 1.5 & 1.2 & 1.6 & 1.5 & 1.3 & 1.0 & 1.4 & 1.2 & 1.3 & 1.4 & 1.0 & 1.1 & 1.4 & 1.4 & 1.21 & 1.02 & 1.34 \\
\hline $40-80 \mathrm{~cm}$ & 1.1 & 1.4 & 1.6 & 1.3 & 2.3 & 1.6 & 1.2 & 1.0 & 1.5 & 1.4 & 1.5 & 1.5 & 1.1 & & 1.5 & 1.7 & 1.31 & 1.17 & 1.48 \\
\hline$>80 \mathrm{~cm}$ & 2.0 & 1.0 & 1.2 & 1.1 & & 1.0 & 1.3 & & 1.2 & 1.33 & 1 & 1.21 & & 1 & 1.1 & 1.5 & 1 & 1 & 1.17 \\
\hline \multicolumn{20}{|l|}{ Nekton } \\
\hline $\begin{array}{l}<10 \mathrm{~cm} \\
10-20 \mathrm{~cm}\end{array}$ & $\begin{array}{r}8.7 \\
18.9\end{array}$ & $\begin{array}{l}35.1 \\
34.3\end{array}$ & $\begin{array}{r}9.1 \\
14.8\end{array}$ & $\begin{array}{r}5.6 \\
56.5\end{array}$ & 52.2 & $\begin{array}{r}32.4 \\
9.1\end{array}$ & $\begin{array}{r}5.3 \\
15.9\end{array}$ & $\begin{array}{r}100 \\
36.6\end{array}$ & $\begin{array}{l}38.1 \\
45.5\end{array}$ & $\begin{array}{l}3.23 \\
6.76\end{array}$ & $\begin{array}{l}28.8 \\
20.1\end{array}$ & $\begin{array}{l}18 \\
16\end{array}$ & $\begin{array}{l}41.4 \\
77.8\end{array}$ & $\begin{array}{r}0 \\
13.9\end{array}$ & $\begin{array}{r}24 \\
21.3\end{array}$ & $\begin{array}{l}15.1 \\
17.5\end{array}$ & $\begin{array}{l}33.3 \\
19.6\end{array}$ & $\begin{array}{r}0 \\
68.6\end{array}$ & $\begin{array}{l}22.3 \\
20.7\end{array}$ \\
\hline $20-40 \mathrm{~cm}$ & 31.4 & 22.9 & 20.6 & 37.9 & 33.3 & 13.6 & 25.3 & 78.4 & 27 & 13.5 & 19.1 & 20 & 84.9 & 10.9 & 16.6 & 18.8 & 10.7 & 85.5 & 22.6 \\
\hline $40-80 \mathrm{~cm}$ & 52.4 & 12.6 & 27.6 & 36.6 & 11.4 & 14.7 & 61.1 & 100 & 29.5 & 22.3 & 14.9 & 25.6 & 72.7 & & 22 & 14 & 38.5 & 74.3 & 26 \\
\hline$>80 \mathrm{~cm}$ & 50.0 & 76.9 & 86.2 & 82.5 & & 100 & 75.8 & & 75.5 & 75 & 100 & 77.9 & & 100 & 75 & 71 & 78.6 & 100 & 81.7 \\
\hline \multicolumn{20}{|l|}{ Crustacean } \\
\hline$<10 \mathrm{~cm}$ & 87.0 & 38.3 & 49.1 & 77.8 & & 40.4 & 68.4 & 0.0 & 11.9 & 63.9 & 66.3 & 58.3 & 18.4 & 88.9 & 67.7 & 47.7 & 33.3 & 100 & 53 \\
\hline $10-20 \mathrm{~cm}$ & 77.4 & 51.3 & 52.0 & 37.5 & 47.8 & 53.6 & 60.3 & 42.8 & 34.3 & 53.3 & 66.2 & 55 & 21.1 & 84.5 & 64.2 & 50.9 & 64.4 & 25.7 & 53.4 \\
\hline $20-40 \mathrm{~cm}$ & 52.9 & 34.1 & 39.4 & 33.9 & 49.7 & 41.6 & 34.7 & 16.2 & 27.7 & 50.9 & 50.1 & 38.3 & 14.5 & 78.4 & 37.5 & 31.4 & 68.9 & 13.4 & 37.7 \\
\hline $40-80 \mathrm{~cm}$ & 31.7 & 19.5 & 23.8 & 27.8 & 75.7 & 20.2 & 19.5 & 0.0 & 22.6 & 24.5 & 26.1 & 23.5 & 18.2 & & 23 & 23.4 & 53.6 & 18.5 & 23.5 \\
\hline$>80 \mathrm{~cm}$ & 0.0 & 15.4 & 9.3 & 10.0 & & 0.0 & 16.3 & & 14.8 & 16.7 & 0 & 13.6 & & 0 & 14.3 & 19.5 & 14.3 & 0 & 11.3 \\
\hline \multicolumn{20}{|l|}{ Echinoderms } \\
\hline $10-20 \mathrm{~cm}$ & 1.4 & 1.8 & 2.9 & 1.4 & 0.0 & 1.2 & 3.7 & 3.7 & 4.52 & 1.09 & 2.79 & 2.8 & 0 & 1.32 & 3.08 & 2.83 & $\begin{array}{r}0 \\
0.65\end{array}$ & 0 & 2.5 \\
\hline $20-40 \mathrm{~cm}$ & 2.1 & 10.6 & 3.5 & 3.9 & 5.3 & 5.3 & 11.7 & 0.0 & 8.6 & 4.5 & 5.39 & 7.4 & 0 & 0 & 8.4 & 9.5 & 3.09 & 0 & 7.02 \\
\hline $40-80 \mathrm{~cm}$ & 1.4 & 7.2 & 5.7 & 3.3 & 3.6 & 7.4 & 6.2 & 0.0 & 5.9 & 3.85 & 9.2 & 5.7 & 0 & & 5.9 & 7.9 & 0.52 & 2.54 & 5.66 \\
\hline$>80 \mathrm{~cm}$ & 50.0 & 0.0 & 1.7 & 2.5 & & 0.0 & 2.9 & & 1.75 & 8.33 & 0 & 2.93 & & 0 & 3.57 & 3.5 & 0 & 0 & 2.43 \\
\hline \multicolumn{10}{|l|}{ Molluses } & 3.23 & 2.5 & 6.25 & 0 & 11.1 & 4.17 & 5.66 & 0 & 0 & 5.43 \\
\hline $10-20 \mathrm{~cm}$ & 2.3 & 5.7 & 10.7 & 2.9 & 0.0 & 10.2 & 9.7 & 7.5 & 9.97 & 11.5 & 4.71 & 9.76 & 0.57 & 0.26 & 7.3 & 10.1 & 10.5 & 0 & 8.74 \\
\hline $20-40 \mathrm{~cm}$ & 9.0 & 27.0 & 31.5 & 19.0 & 2.8 & 34.1 & 23.5 & 2.7 & 32.8 & 23.3 & 19.2 & 28.9 & 0.68 & 7.5 & 32.3 & 34.4 & 11.3 & 1.04 & 27.4 \\
\hline $40-80 \mathrm{~cm}$ & 13.3 & 54.8 & 38.2 & 29.4 & 5.7 & 51.7 & 9.9 & 0.0 & 37.9 & 44.6 & 43.1 & 40.5 & 9.09 & & 44.4 & 48.9 & 3.13 & 1.43 & 40.3 \\
\hline$>80 \mathrm{~cm}$ & 0.0 & 7.7 & 2.9 & 5.0 & & 0.0 & 5.0 & & 8 & 0 & 0 & 5.52 & & 0 & 7.14 & 6 & 7.14 & 0 & 4.57 \\
\hline \multicolumn{20}{|l|}{ Worms } \\
\hline$<10 \mathrm{~cm}$ & 0.0 & 16.0 & 41.8 & 0.0 & & 25.4 & 15.8 & 0.0 & 35.7 & 26.5 & 2.5 & 15.9 & 34.2 & 0 & 2.08 & 31.5 & 0 & 0 & 18.2 \\
\hline $10-20 \mathrm{~cm}$ & 0.0 & 4.2 & 18.9 & 0.8 & 0.0 & 24.2 & 9.7 & 7.2 & 4.47 & 25.4 & 5.88 & 15.1 & 0.57 & 0 & 3.79 & 17.3 & 4.14 & 0 & 13.5 \\
\hline $20-40 \mathrm{~cm}$ & 1.9 & 4.3 & 4.4 & 2.6 & 1.4 & 4.8 & 4.3 & 2.7 & 3.52 & 5.39 & 4.83 & 4.4 & 0 & 2.5 & 4.11 & 4.73 & 4.52 & 0 & 4.19 \\
\hline $40-80 \mathrm{~cm}$ & 0.9 & 4.4 & 3.3 & 1.4 & 3.6 & 5.0 & 1.4 & 0.0 & 2.85 & 3.68 & 5.71 & 3.4 & 0 & & 3.59 & 4.85 & 3.88 & 0 & 3.37 \\
\hline$>80 \mathrm{~cm}$ & 0.0 & 0.0 & 0.0 & 0.0 & & 0.0 & 0.0 & & 0 & 0 & 0 & 0 & & 0 & 0 & 0 & 0 & 0 & 0 \\
\hline
\end{tabular}

other biotopes showing no specific trend of worm volume in stomachs as fish size increases. This trend is also very significant for non cryptic species, species with a large home range, species which are daytime active and species with small to medium school size (Table 5).

\section{Molluscs}

The relationship between the relative number of species feeding on molluscs and fish size is not linear but dome shaped, the same being true for the relationship between the volume of molluscs in stomachs and fish size (Fig. 3). The importance of molluscs for medium size fish $(20-80 \mathrm{~cm})$ is mainly marked for reefs and soft bottoms. This dome shaped curve is observed for all home ranges and nycthemeral activities but restricted to small schooling species and non cryptic species (Table 5).

\subsection{Taxonomic level}

\subsubsection{All families}

Families play a very significant role in determining the number of prey types and the volume of the various food 
items (Table 3). Fish is the major food item of three of the studied families: Synodontidae, Sphyraenidae and Carangidae, this item representing more than $70 \%$ on average of the stomach content within these families (Table 2). All species within these three families have fish as their major food item (Appendix I). As the level of piscivory decreases, the importance of crustaceans increases, this prey group making more than $60 \%$ of the diet of Mullidae and Haemulidae (Table 2). Crustaceans represent the major item for all 9 species of Mullidae studied, whereas crustaceans represent a major item for only 3 out of the five species of Haemulide studied (Appendix I). Molluscs are an important item (more than $25 \%$ of the diet) for only three of the studied families (Table 2): Lethrinidae (31\%), Tetraodontidae (41\%) and Balistidae $(50 \%)$. The importance of molluscs within these three families is however very uneven, with some species eating very little of this item, whilst others eat more than $50 \%$. In all cases gasteropods are much less eaten than bivalves, probably because they are harder to crack. Interestingly it is these same three families which consume the most echinoderms (Table 2), but this item accounts at best for $11 \%$ of the diet (Tetraodontidae). Echinoderms is in addition an irregular prey item within these families, except for Lethrinidae. Most echinoderms eaten by Lethrinidae are sand dwelling ones. Worms are consumed in significant amounts only by families which frequent soft bottoms (Table 2): Bothidae (28\%), Nemipiteridae (23\%) and Mullidae (10\%). This item is however eaten only by specific species within these families (Scolopsis taenioptera, Parupeneus heptacanthus, Upeneus australiae and Engiprosopon grandisquamma). With the exception of Balistidae and Tetraodontidae, "others" is not an important food group for the carnivorous species investigated in our study.

\subsubsection{Major families}

Three families, Lethrinidae, Lutjanidae and Serranidae, make $61.3 \%$ of the observed occurrences. All three families eat mainly crustaceans, fish and molluscs. However, the relative importance of these items is different for these families, nekton being more important for Serranidae than for the two other families, crustaceans being of similar value for Serranidae and Lutjanidae. Lethrinidae tend to prefer less mobile prey as attested by the lower importance of nekton and crustaceans in their diet. To compensate, Lethrinidae eat more molluscs than Serranidae or Lutjanidae.

These differences between families may be in part attributed to the biotope; Lethrinidae ranging over both reefs and soft bottoms, whereas Lutjanidae and Serranidae are mainly reef feeders. There are also differences in foraging behaviours. Lutjanidae and Lethrinidae are schooling species. Two traits are associated to schooling in these families: 1- school size decreases with fish size; 2- larger fish have a larger home range. Schooling fish will tend to eat aggregated prey such as bivalve, sand urchin or small pelagic fish (sprat and anchovy are frequent prey for schooling Lutjanidae). Solitary fish within these families usually eat mobile prey, e.g. Lethrinus olivaceus, Aprion virescens, Symphorus nematophorus, large Lutjanus sebae or Lethrinus nebulosus will have a majority of fish in their diet. Serranidae (Epinephelinae) are all solitary species. They typically ambush their prey which are most of the time mobile (e.g. fish and crustaceans). These fish are not equipped to crush molluscs but they usually can manage to eat hard shelled crustaceans. The only time Serranidae are found in groups (not schools) is when they reproduce or when they feed on schools of small pelagic fish (Clupeidae and Atherinidae mainly).

A closer look at variations of diet with size within the three major families (Serranidae, Lutjanidae and Lethrinidae) shows that there are some convergences in their patterns. Finfish tended to increase in importance with predator size in all three families, whereas crustaceans tended to decrease for all three families as predator size increased (Fig. 4). There was no clear pattern for the other prey types with size within these families, except for the molluscs and echinoderms for Lethrinidae (Fig. 5). The importance of molluscs increased to nearly $55 \%$ of mean diet composition of Lethrinidae in the $40-50 \mathrm{~cm}$ size range and decreased rapidly afterwards. Echinoderms displayed a different pattern, their importance decreasing for Lethrinidae past $30 \mathrm{~cm}$, this item never exceeding $20 \%$ for these fish.

\subsubsection{Differences within a family}

There are major differences in the diet of species within a family. To illustrate this, we chose to investigate three species of Lethrinidae. These three species, Lethrinus atkinsoni, L. nebulosus and L. rubrioperculatus have different life history traits. L. atkinsoni reaches a size of $43 \mathrm{~cm}$ and $2 \mathrm{~kg}$, lives in small schools and is found in all lagoon biotopes except mangroves and estuaries. L. nebulosus reaches $70 \mathrm{~cm}$ and over $6 \mathrm{~kg}$, lives in medium to large size schools, it is usually found on soft bottoms, algae and sea grass beds and near reefs, but is usually not seen on the reefs themselves. L. rubrioperculatus is a small species ( $35 \mathrm{~cm}$ for $1 \mathrm{~kg}$ ), often found in large schools and restricted to hard bottoms, usually in areas under oceanic influence (passes and barrier reefs).

Both L. nebulosus and L. atkinsoni are compressed high bodied fish, whereas L. rubrioperculatus is elongated. For a similar size, L. nebulosus will tend to have a higher diversity of prey (except for fish $<15 \mathrm{~cm}$ ), whilst $L$. atkinsoni has a decreasing number of prey items with size and L. rubrioperculatus has a stable diversity of prey with size. These three species have different overall diet compositions (Fig. 5). L. nebulosus eats mainly molluscs, followed by crustaceans and echinoderms, whilst $L$. atkinsoni has a balanced diet with nekton, crustaceans, echinoderms and molluscs having nearly the same value, and $L$. rubrioperculatus has a diet dominated by crustaceans and fish, the former declining with size whilst the latter increases. The diet composition is the most variable with size for L. rubrioperculatus. L. rubrioperculatus eats mainly moving prey (crustaceans and nekton); it has an elongated body like most other Lethrinidae which eat these prey items mainly as well (L. olivaceus, L. xanthocheilus, L. variegatus). However, body shape within the family is not sufficient to predict prey type, as L. miniatus, which has an elevated body, is also essentially piscivorous, and L. genivittatus which is elongated has a very diversified diet with little moving prey. 
LETHRINIDAE
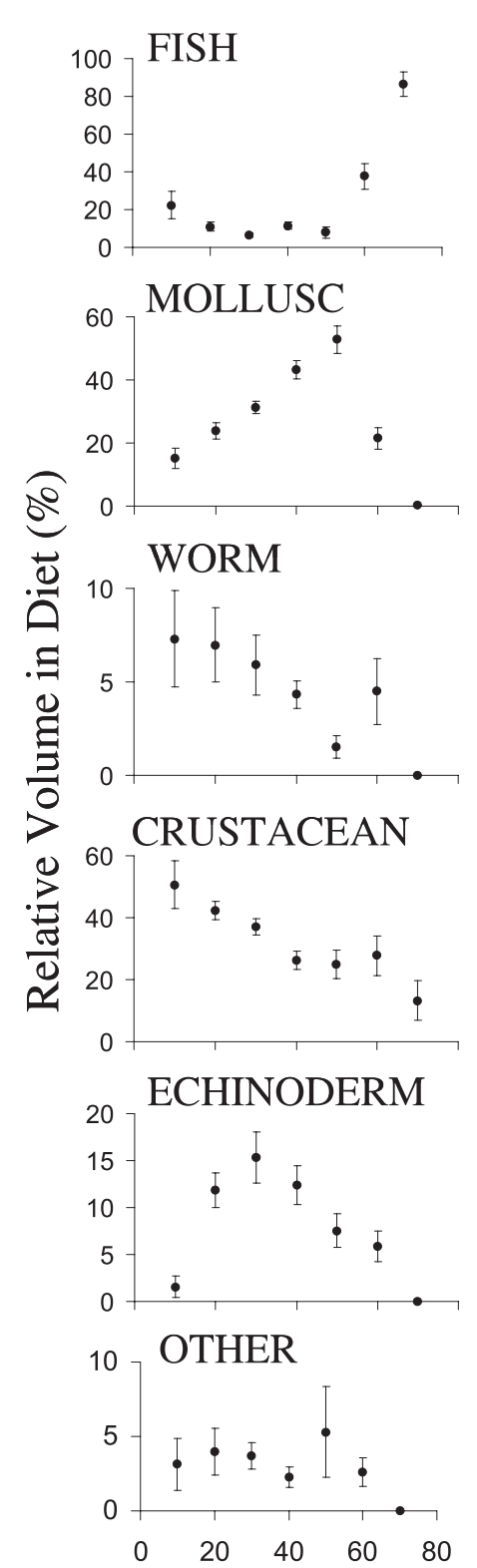

LUTJANIDAE
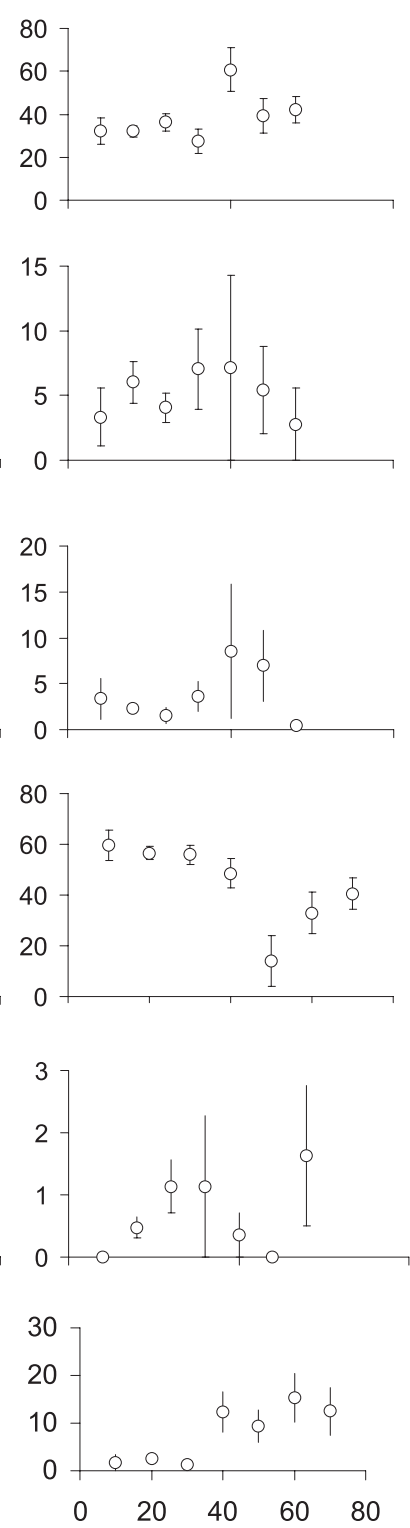

SERRANIDAE
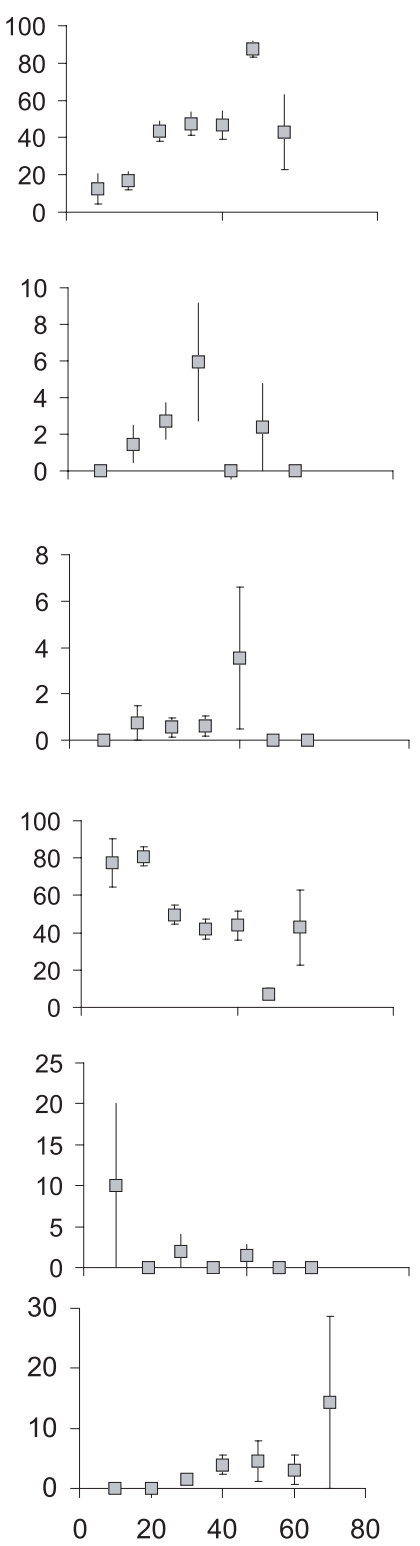

Size Classes $(\mathrm{cm})$

Fig. 4. Relative volumetric contribution in Lethrinidae, Lutjanidae and Serranidae for the successive size classes cm) (see Fig. 3 for details on calculation). Error bars indicate the standard deviation for each mean.

\section{Discussion}

The present study on stomach contents encompasses more species of carnivorous fishes than any other to date (e.g. the most extensive studies published so far on the diets of IndoPacific coastal fishes are Hiatt and Strasburg 1960; Hobson 1974; Harmelin-Vivien 1979; Sano et al. 1984; Parrish 1987; Pinto 1987; Nakamura et al. 2003). However, this study looked mainly at large species, most small carnivorous species such as Apogonidae, small Labridae (e.g. genera Halichoeres, Coris, Thalassoma), Scorpaenidae, Callyonimidae, Leiognathidae or flatfishes are not covered by our study. The diets of such species which are often amongst the most abundant species in tropical coastal waters of the Indo-Pacific are little known.

The number of prey types was low, but this is in great part due to the low number of types (6) retained for the analysis. Most species are opportunistic, eating what is available within a more or less restricted range of items. Changes in the number of prey types should reflect both this plasticity and the variability of prey in the biotopes where the fishes feed. This is reflected by our finding that the number of prey types increased with biotope complexity and with the home range of the species. An interesting point is that night active species tend to have a higher diversity of prey types probably because 

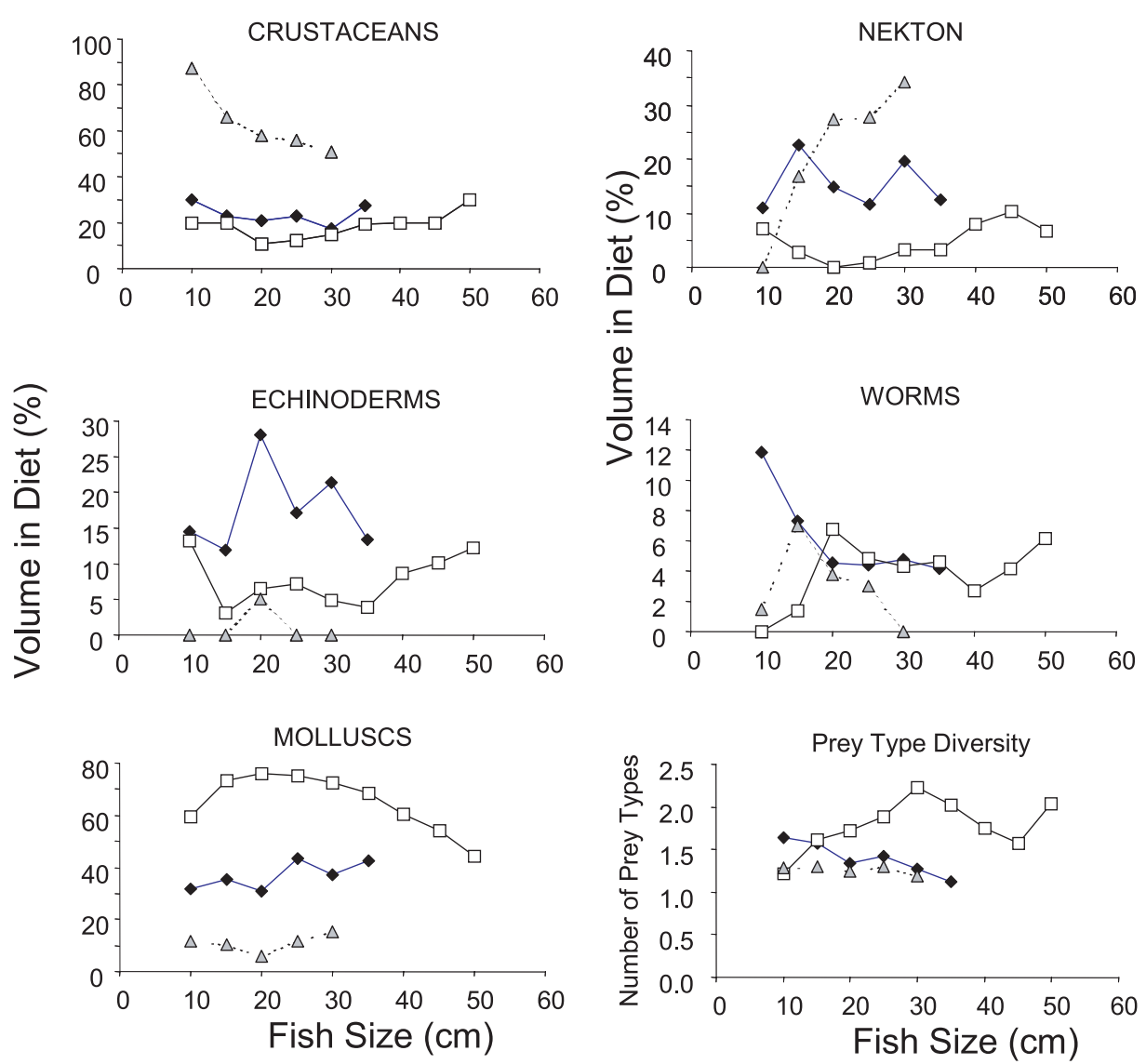

$\bullet$ L.atkinsoni $\quad-\square$ - L.nebulosus $\quad \backsim$ L.rubriopeculatus

Fig. 5. Variations of prey items and prey diversity according to species and size within Lethrinidae.

most benthic invertebrates are only active at night trying to escape predation.

The most frequently eaten prey items (fish, crustaceans, molluscs, worms and echinoderms) are the same than in all other studies on the diet of tropical carnivorous coastal fishes. The frequency of these items is probably not necessarily proportional to their abundance in the environment. Our study does not investigate this relationship between prey abundance in the biotope and prey occurence in the diet, however it indirectly points to this as the importance of prey in the diet were linked to biotope, home range and fish behaviour (Tables 3 and 4). There are few studies relating the diet of large carnivorous reef fish with food availability in the tropics (HarmelinVivien 1981; Parrish et al. 1985). Jones et al. (1991), about Diagramma pictum and Lethrinus nebulosus on the Great Barrier Reef, indicated that these fish fed on available molluscs but that the size range of their prey depended on the fish and not on prey abundance. Egretaud (1992) showed little correlation between the observed diet of 1400 Lethrinus nebulosus, and the food items found during a simultaneous benthos study (Clavier et al. 1992; Clavier and Garrigue 1993) on 64 stations on Ouvea atoll (New Caledonia). In particular, many abundant benthic organisms were not found in the stomachs of Lethrinus nebulosus even though these invertebrates were part of the diet of this fish. On the opposite, some items in their diet were not found or found in minute quantities during the benthos survey. This indicates that carnivorous fish choose their food items and do not necessarily feed on the most abundant items even if the latter are suitable. This is confirmed by Beukers-Stewart and Jones (2004) who showed that the feeding rate of two Serranidae was not linked to biotope despite differences in prey abundance.

Predation is thought to be a major determinant in structuring reef fish assemblages (e.g. Hixon 1991; Planes and Lecaillon 2001; Stewart and Jones 2001) and our data indicate that fish was the major food item for large carnivorous fishes in New Caledonia. Piscivory by small fish is certainly also high, fishes such as the labrids Halichoeres and Thalassoma or some Apogonidae (e.g. Cheilodipterus spp.) being often abundant on reefs. Night feeding and cryptic species such as the Holocentridae and most anguilliform fishes (Muraenidae, Congridae, Ophichtidae, Scorpaenidae) are probably more abundant than usually indicated by visual reef fish surveys (Kulbicki 1990) and consequently may represent a major but unsuspected source of piscivory.

Our data show that biotope does not play the same role on the volume of the various prey types eaten by large carnivorous fishes. There is a gradient in the complexity of the biotopes we considered, reefs being the most complex and pelagic the least, nearshore and soft bottoms being intermediate. There seems to 
be a relationship between the type of protection displayed by prey and this complexity, prey speed being linked to poor complexity, physical defenses (e.g. shell thickness or cover, spines) increasing as biotope complexity decreases. There is little or no information in the literature on the links between prey characteristics and biotope complexity. However, there is a strong link between biotope complexity and the abundance and diversity of reef fish assemblages (e.g. Friedlander and Parrish 1998; Parrish and Bolland 2004) and consequently on the diversity of feeding modes.

Home range of fish is a significant factor in the level of several prey types in our study (Tables 3 and 4). The trends we observe seem at first opposite to logic. Species with a large home range are usually large species and therefore nekton should represent a larger part of their diet than for species with small home range. The opposite is observed. Similarly molluscs, and worms which may be eaten by small species are found in much higher volumes in species with a large home range. One possible explanation could be found in the nutritional values of these items. Nekton is most of the time of higher nutritional value than worms or molluscs and therefore lesser quantities are needed and may be obtained from a more restricted area.

Most herbivorous and plankton feeding species tend to form schools, but the causes and consequences of this behaviour are not well known (e.g. for herbivores, see Wolf 1987; Choat and Clements 1998; Choat et al. 2004 or Floeter et al., in press). Consequences of schooling on the diet of carnivorous fishes is not well documented, most studies considering the benefits of schooling for the prey not for the predator (e.g. Krause et al. 1998; Hemelrijk and Hanspeter 2005). Our study shows that even though prey volume is not affected by this factor, it does influence the choice of prey to some extent. For instance, nekton is eaten either by solitary species (mainly species ambushing their prey) or by species forming large schools (which may be more efficient in pursuing nekton). Several of our findings are however difficult to explain, e.g. why don't pairing carnivorous species eat molluscs, or why worms are mainly eaten by species forming small schools?

Nycthemeral activity is a very significant factor for the volume of prey. There are strong relationships between predator and prey behaviours (e.g. Temming et al. 2004; Stoner 2004) which are reflected in the choice of prey and feeding time. In our case several prey groups tend to be nocturnal: echinoderms, crustaceans and gasteropods. Therefore they are more vulnerable during that time and consequently are less targeted by day active species. Nekton may also be more vulnerable at night as many small reef fish species, which may be predated by piscivores, are active only during the day and rest motionless during the night. Day active fish eat more worms than other species. Worms tend to stay hidden at all times and therefore night feeding should present no specific advantage for this food type.

Crypticity is an important factor for some diet items in our study. Cryptic species eat no echinoderm, which indicates that this behaviour has no use for such prey types. On the opposite such species have the highest level of nekton in their diet, thus indicating that ambushing fish is probably more successfull than chasing them, at least in terms of energy. Interstingly, the most cryptic species are those which specialise on crustaceans.
Most crustaceans are night active. Being prey of very cryptic fish, when light conditions are at the lowest, suggests that these prey are able to detect, most likely by sight, less cryptic predators. On the opposite, the non cryptic species are those which consume essentially prey with little or no sighting abilities (worms, echinoderms and molluscs).

Fish diet is highly linked to fish size as demonstrated by numerous studies which show that it acts on prey preference, prey diversity, feeding behaviour or feeding rate. Our study confirms the relationship between fish size and number of prey items (prey types in our case). Several authors found that this relationship was not linear but first increased, then as the fish got to their maximum size, the diversity of their prey tended to decrease, thus showing a specialisation with size or age (e.g. Harmelin-Vivien 1981, 1989; Lundvall et al. 1999; St John 1999). This parabolic trend was also detected in our data for 22 species, but a linear fit was usually better ( 25 species); thus, such a trend is not necessarily general. This relationship depended on the biotope and home range, being more important for reefs and for species with large home range (Table 5). This is probably linked to prey availability, the diversity of prey being much higher on reefs and species with a larger home range being able to access more prey types.

The present study, as many others (e.g. McCormick 1998; Piet 1998; Jennings et al. 2001; Hanson and Chouinard 2002; Nakamura et al. 2003) indicates that there may be important changes of diet with size, many species switching from smaller, easier to access prey, to larger prey or to prey more difficult to catch or extract but of higher nutritive value. It is difficult to assess the consequence of such shifts in terms of energy flow as well as in terms of impact on the environment (Jones et al. 1991). These changes in diet with size go often together with a change in biotope. For instance, Egretaud (1992) found that the smaller Lethrinus nebulosus were found in the shallowest parts of the Ouvea lagoon where they fed on relatively small sand dwelling prey, whereas the larger specimen were found in the deeper parts of the lagoon and fed on larger mobile prey. More interestingly, the feeding schedule of these fish suggested that adult fish would travel great distances to feed whereas the smaller fish tended to stay within the same area. In other words, larger fish can cover wider feeding grounds and choose amongst a wider category of prey, the smaller fish being limited by factors such as their swimming abilities or predation by larger fish.

Nekton was an increasingly important diet item as fish size increased, with more species eating this item as size increased. Nekton probably offers the best nutrional input for carnivorous fish and is therefore favored when possible. Access to nekton depends in great part on predator swimming speed (see review by Domenci and Blake 1997), as attested by the fact that the largest fish sizes $(>80 \mathrm{~cm})$ eat a far larger proportion of nekton than the smaller size classes (Table 5), this being true for all behaviour types (schooling, crypticity, diel activity) and all biotopes. Swimming speed is not the only factor in play, as one notices that cryptic species eat more nekton than other species for all size classes. This suggests that either cryptic species are more efficient in getting nekton, or that they are more specialized. As these fish ambush their prey, it is their initial speed 
more than their sustained speed which is important (Domenci and Blake 1997).

Crustaceans decrease in importance in the diet of most fishes as size increases. This has been observed in other ecosystems, carnivorous fishes switching from crustacean to nekton as they grow (e.g. Cardinale 2000; Hanson and Chouinard 2002). This prey type seems specifically important for small reef species with a short home range. Prey abundance in the various biotopes is not available, but shrimps and crabs may be observed in large numbers on reefs at night, whereas they are seldom seen in the other biotopes, except nearshore (seagrass and algae beds, mangroves and estuaries) where this prey item is also important but for larger size species than on reefs.

Predation of urchins on reefs has received special attention as urchins compete with herbivorous fishes for turf algae (Hay and Taylor 1985; Carpenter 1988; McClanahan 1994, 1999). The increase of urchins by the removal of their fish predators through fishing may affect the growth of turf algae which in turn will affect herbivorous fish and even the entire ecosystem by cascade effect (Hughes 1994). The present study indicates that reef urchins were not a preferred food and it was a prey item only for the largest Lethrinidae. Our data did not cover well other potential urchin predators such as large Labridae, Tetraodontidae and Balistidae, but these fish are usually not abundant on reefs in New Caledonia (Kulbicki 1997; Letourneur et al. 2000) and are not targeted by fishermen in general. Therefore, the control of urchin by fish may not occur on large urchins, but rather on their very initial stages. These are probably preyed upon by small species (e.g. small Labridae, Monacanthidae, Balistidae) or accidentaly destroyed by grazers (Scaridae, Acanthuridae). This might explain the lack of a direct link between the abundance and sizes of large predatory fish and the abundance of reef urchins in the south west Pacific (Mitchell 2004) opposite to the results in the Western Indian Ocean (McClanahan 1994). In our study, no pattern could be detected between the importance of urchin as prey and fish size, but this prey item was mainly eaten by large fish.

Worms never represented a high volume in the diet of the fish examined, probably due to the fact that this prey type is small, difficult to find and maybe of low nutritional value compared to other prey types. This prey type significantly decreased with fish size, especially on soft bottoms (where this prey is the most important), for non cryptic, daytime active species and species with a large home range and small to medium size schools (Table 5). It is likely that worms are not found in sufficient quantities to feed large fish and that these prey are probably found in aggregates which would favor schooling fish (schooling is known to favor the finding of prey with patchy distributions - e.g. Ward et al. 2000).

The importance of molluscs in the diet of carnivorous fishes from New Caledonia displays a dome shaped curve as size increases. It is general to most behaviours and most marked for reefs and soft bottoms (Table 5). Eating molluscs requires powerful jaws and this may not be reached before a given size; thus explaining the low contribution of this prey type to the diet of small fishes. The absence of molluscs in the largest fishes could be due to a low nutritional value compared to the energy needed to consume large enough quantities. Large molluscs are not very abundant in the coastal waters of New Caledonia (Clavier et al. 1992) and the few species which are available are usually gasteropods with very thick shells which can be crunched only by very well adapted fish species (i.e. Balistidae, Tetraodontidae, some of the largest Labridae and Lethrinidae).

All the factors analysed so far in this article are not sufficient to explain all the observed variations in fish diet. There are major and significant differences due to taxonomy (Table 3), each family and each species within a family having specific requirements. The differences between families are intrinsic. For instance, Nemipteridae and Mullidae share many characteristics in common (size, behaviour, biotopes), the former prefering worms and the latter shrimps. On the opposite differences between the three major families (Serranidae, Lutjanidae, Lethrinidae) may be in great part explained by differences in behaviour and biotopes. This allows for a better allocation of resources amongst species within the fish assemblage. It shows in particular that creating large trophic categories based on major prey types, as is usually done for reef fishes (see review Kulbicki 1991), may hide important differences in targeted prey.

Differences within a family may also be important as indicated by the studied example of the Lethrinidae. In this case, some of the differences may be explained by the general factors considered earlier (biotope, size, behaviour), but there remain differences which are intrinsic to the species. For instance L. rubrioperculatus, despite its smaller size, eats more fish than the two other species. Its elongate shape is an advantage to eat fish, but not a sufficient explanation, as some high bodied Lethrinidae are also mainly piscivores.

The present study brings information on the diet of large carnivorous fish, but we still need much more information on the diet of fish if we wish to achieve adequate trophic models. Amongst carnivorous species, the main needs are towards the smaller species (Apogonidae, Labridae, Nemipteridae, Gobiidae, etc.) which often make the bulk of the abundance in lagoons, even though their contribution to biomass is often low.

Acknowledgements. We wish to thank the many persons who assisted in the collection and the dissection of the fish analyzed in this study, especially the crews of the RV Alis, Dawa and Dar Mad, Nicolas Audran and Pierre Boblin.

\section{References}

Abu Khair M.M., Ambak M.A., Zaki Bin Mohamed Said M., Sakiam M., Hayase S., 1990, A study on the feeding habits of fishes in the South-Western portion of the South China Sea. In: Abu Khair M.M, Abdul Rahman R., Ambak M.A. (Eds.) Ekspedisi Matahari '86 Faculty of Fisheries and Marine Science. Pertanian University Malaysia, Occasional Publ. 4, 159-172.

Beukers-Stewart B.D, Jones G.P., 2004, The influence of prey abundance on the feeding ecology of two piscivorous species of coral reef fish. J. Exp. Mar. Biol. Ecol. 299, 155-184. 
Blaber S.J.M., 1980, Fish of the Trinity inlet system of north Queensland with notes on the ecology of the fish faunas of tropical Indo-Pacific estuaries. Aust. J. Mar. Freshw. Res. 31, 137-146.

Blaber S.J.M., D.A. Milton, Rawlinson N.J.F., 1990, Diets of lagoon fishes in the Solomon Islands: predators of tuna baitfish and trophic effects of baitfishing on the subsistence fishery. Fish. Res. 8, 263-286.

Bozec Y.M., Kulbicki M., Chassot E., Gascuel D., 2005, Trophic signature of coral reef fish assemblages: Towards a potential indicator of ecosystem disturbance. Aquat. Living Resour. 18, 103-109.

Cardinale M., 2000, Ontogenetic diet shifts of bull-rout, Myoxocephalus scorpius (L.), in the south-western Baltic Sea. J. Appl. Ichthyol. 16, 231-239.

Carpenter R.C., 1988, Mass mortality of a Caribbean sea urchin: Immediate effects on community metabolism and other herbivores Proc. Natl. Acad. Sci. USA 85, 511-514.

Carpenter K.E., Niem V.H., 2000, FAO species identification guide for fisheries purposes. the living marine resources of the Western Central Pacific. FAO Rome, 1-6.

Choat J.H., Clements K.D., 1998, Vertebrate herbivores in marine and terrestrial environments: a nutrinional ecology perspective. Annu. Rev. Ecol. Syst. 29, 375-403.

Choat J.H, Robbins D., Clements K.D., 2004, The trophic status of herbivorous fishes on coral reefs. Mar. Biol. 145, 445-454.

Clavier, J., Garrigue C., 1993, Étude du benthos de l'atoll d'Ouvéa. In: Évaluation des ressources en poissons du lagon d'Ouvéa : 1ère partie - l'environnement biologique, le macrobenthos, le megabenthos et le plancton. Rapp. Conv. Sci. Mer ORSTOM Nouméa 8, 1-36.

Clavier J., Garrigue C., Bargibant G., Di Matteo A., Hamel P., Kulbicki M., Urbain R., 1992, Étude quantitative du benthos dans le lagon d'Ouvéa. Liste taxonomique, densité et biomasses du macrobenthos, ATP, pigments photosynthétiques et matière organique dans le sédiment. Rapp. Scient. Techn. Sci. Mer Biologie marine ORSTOM Nouméa, 64.

Cury P., Shannon L., Shin Y.-J., 2002, The functioning of marine ecosystems: a fisheries perspective. In: Sinclair M., Valdimarsson G. (Eds.) Responsible Fisheries in the Marine Ecosystem, CAB International, pp. 103-123.

Domenci P., Blake R.W., 1997, Review: the kinetics and performance of fish fast-start swimming. J. Exp. Biol. 200, 1165-1178.

Egretaud C., 1992, Étude de la biologie générale et plus particulièrement du régime alimentaire de Lethrinus nebulosus du lagon d'Ouvéa. DAA, ENSA Rennes Halieutique.

Floeter S.R., Behrens M.D., Ferreira C.E., Paddack M.J., Horn M.H. in press Geographical gradients of marine herbivorous fishes: patterns and processes. Mar. Biol.

Friedlander A.M., Parrish J.D., 1998, Habitat characteristics affecting fish assemblages on a Hawaiian coral reef. J. Exp. Mar. Biol. Ecol. 224, 1-30.

Froese R., Pauly D., 2000, Fishbase 2000, Concepts, design and data sources. ICLARM, Los Banos, Laguna, Philippines.

Gascuel D., Bozec Y.-M., Chassot E., Colomb A., Laurans M., 2005, The trophic spectrum: theory and application as an ecosystem indicator. ICES J. Mar. Sci. 62, 443-452.

Hanson J.M., Chouinard G.A., 2002, Diet of Atlantic cod in the southern Gulf of St Lawrence as an index of ecosystem change, 1959-2000. J. Fish Biol. 60, 902-992.

Harmelin-Vivien M.L., 1979, Ichtyofaune des récifs coralliens de Tuléar (Madagascar) : Écologie et relations trophiques. Ph.D. Thesis University Aix-Marseille II.

Harmelin-Vivien M.L., 1981, Trophic relationships of reef fishes in Tuléar (Madagascar). Oceanol. Acta 4, 365-374.
Harmelin-Vivien M.L., 1989, Reef fish community structure: an Indo-Pacific comparison. In: Harmelin-Vivien M.L., Bourlière F. (Eds.), Ecological studies. Vertebrates in complex tropical systems, New York, Springer Verlag, 69, 21-60.

Harmelin-Vivien M., Kaim-Malka R.A., Ledoyer M., Jacob-Abraham S.S., 1989, Food partinioning among Scorpaenid fishes in Mediterranean seagrass beds. J. Fish Biol. 34, 715-734.

Hay M.E., Taylor P.R., 1985, Competition between herbivorous fishes and urchins on Caribbean reefs. Oecologia 65, 591-598.

Hemelrijk C., Hanspeter K., 2005, Density distribution and size sorting in fish schools: an individual based model. Behav. Ecol. 16, 178-187.

Hiatt R.W., Strasburg D.W., 1960, Ecological relationships of the fish fauna on coral reefs of the Marshall islands. Ecol. Monogr. 30, 65-127.

Hixon M.A., 1991, Predation as a process structuring coral reef fish communities. In: Sale P.F. (Ed.) The Ecology of Fishes on Coral Reefs. New York, Academic Press, pp. 475-507.

Hobson E.S., 1974, Feeding relationships of teleostean fishes on coral reefs in Kona, Hawaii. Fish. Bull. 72, 915-1031.

Hughes T.P., 1994, Catastrophes, phase shifts, and large scaledegradation of a Caribbean coral reef. Science 265, 1547-1551.

Jennings S., Pinnegar J.K., Polunin N.V.C., Boon T.W., 2001, Weak cross-species relationships between body size and trophic level belie powerful size-based trophic structuring in fish communities. J. Anim. Ecol. 70, 934-944.

Jones G.P., Ferrell D.J., Sale P.F., 1991, Fish predation and its impact on the invertebrates of coral reefs and adjacent sediments. In: Sale P. (Ed.) The ecology of fishes on coral reefs. Academic Press, 156-179.

Kingsford M.J., 1992, Spatial and temporal variation in predation on reef fishes by coral trout (Plectropomus leopardus, Serranidae). Coral Reefs 11, 193-198.

Krause J., Ruxton G.D., Rubenstein D., 1998, Is there always an influence of shoal size on predator hunting success? J. Fish Biol. 52, 494-501.

Kulbicki M., 1990, Comparisons between rotenone poisoning and visual counts for density and biomass estimates of coral reef fish populations. Proc. Congr. 1990 Int. Soc. Reef Studies, Noumea 14-18 Nov. $1990,105-112$.

Kulbicki M., 1991, Present knowledge of the structure of coral reef fish assemblages in the Pacific in Coastal resources and systems of the Pacific basin: investigation and steps toward a protective management - UNEP Regional Seas Rep. Stud. 147, 31-53.

Kulbicki M., 1997, Bilan de 10 ans de recherche (1985-1995) par l'ORSTOM sur la structure des communautés des poissons lagonaires et récifaux en Nouvelle-Calédonie. Cybium 21 Suppl., 47-79.

Kulbicki M., Labrosse P., Ferraris J., 2004, Basic principles underlying research projects on the links between the ecology and the uses of coral reef fishes in the Pacific. In: Visser L.E. (Ed.) Challenging Coasts. Transdisciplinary Excursions into integrated coastal zone development. Amsterdam, Amsterdam University Press, pp. 119-158.

Laurans M., Gascuel D., Chassot E., Thiam D., 2004, Changes in the trophic structure of fish demersal communities in West Africa in the three last decades. Aquat. Living Resour. 17, 163-173.

Lundvall D., Svanbäck R., Persson L., Byström P., 1999, Sizedependent predation in piscivores: interactions between predator foraging and prey avoidance abilities. Can. J. Fish. Aquat. Sci. 56, 1285-1292.

Letourneur Y., Kulbicki M., Labrosse P., 2000, Fish stock assessment of the northern New Caledonian lagoons: 1 - Structure and stocks of coral reef fish communities. Aquat. Living Resour. 13, 65-76. 
Letourneur Y., Kulbicki M., Galzin R., Harmelin-Vivien M., 1997, Comparaison des poissons marins de trois îles océaniques tropicales de l'Indo-Pacifique (Réunion, Nouvelle Calédonie, Mooréa). Cybium 21 Suppl., 129-145.

McClanahan T.R., 1994, Kenyan coral reef lagoon fish effects of fishing, substrate complexity, and sea-urchins. Coral Reefs 13, 231-241.

McClanahan T.R., 1999, Predation and the control of the sea urchin Echinometra viridis and fleshy algae in the patch reefs of Glover Reef, Belize. Ecosystems 2, 511-523.

McCormick M.I., 1998, Ontogeny of diet shifts by a microcarnivorous fish, Cheilodactylus spectabilis, relationship between feeding mechanisms, microhabitat selection and growth. Mar. Biol. $132,9-20$.

Mitchell R., 2004, Large scale influence of fishing, fish and habitat on sea urchin abundance on Fijian reefs. Ph.D. Thesis University of Newcastle upon Tyne (GB).

Muller K.E., Fetterman B.A., 2003 Regression and ANOVA: An Integrated Approach Using SAS Software ISBN: 0-471-46943-2, Wiley.

Nakamura Y., Horimonchi M., Nakai T., Sano M., 2003, Food habits of fishes in a seagrass bed on a fringing reef at Iriomote Island, Southern Japan. Ichthyol. Res. 50, 15-22.

Norris J.E., 1985, Trophic relationships of piscivorous coral reef fishes from the northwestern Hawaiian Is-lands. MSc. Thesis University of Hawaii.

Parrish J.D., 1987, The trophic biology of snappers and groupers. In: Polovina J.J., Ralston S. (Eds.) Chap. 9 - Tropical snappers and groupers: biology and fishery management. Westview Press, Boulder, USA, pp. 405-464.

Parrish F.A., Boland R.C., 2004, Habitat and reef-fish assemblages of banks in the Northwestern Hawaiian islands. Mar.Biol. 144, 1065-1073.

Parrish J.D., Callahan M.W., Norris J.E., 1985, The trophic relationships that structure reef communities. Proc. 5th Int. Coral Reef Congr. Tahiti 4, 73-78.

Pauly D., Christensen V., Dalsgaard J., Froese R., 1998, Fishing down marine food webs. Science 279, 860-863.

Pauly D., Palomares M.L., Froese R., Sa-a P., Vakily M., 2001, Fishing down Canadian aquatic food webs. Can. J. Fish. Aquat. Sci. 58, 51-62.

Piet G.J., 1998, Ecomorphology of a size structured tropical freshwater fish community. Environ. Biol. Fish 51, 67-86.

Pinnegar J.K., Jennings S., O'Brien C.M., Polunin N.V.C., 2002, Long-term changes in the trophic level of the Celtic Sea fish community and fish market price. J. Appl. Ecol. 39, 377-390.

Pinto, L., 1987, Environmental factors influencing the occurrence of juvenile fish in the mangrove of Pagbilao, Philippines. Hydrobiologia 150, 283-301.
Planes S., Lecaillon G., 2001, Caging experiment to examine mortality during metamorphosis of coral reef fish larvae. Coral Reef 20, 211-218.

Randall J.E., 1980, A survey of ciguatera at Enewetak and Bikini, Marshall Islands, with notes on the systema-tics and food habits of ciguatoxic fishes. Fish. Bull. 78, 201-249.

Rossier O., Kulbicki M., 2000, A comparison of fish assemblages from two types of algae beds and coral reefs in the South-West lagoon of New Caledonia. Cybium 24, 3-26.

Salini J.P., Blaber S.J.M., Brewer D.T., 1994, Diets of trawled predatory fish of the gulf of Carpentaria, Australia, with particular reference to predation on prawns. Aust. J. Mar. Freshw. Res. 45, $397-411$.

Sano M., Shimizu M., Nose Y., 1984, Food habits of the teleostean reef fishes in Okinawa Island, southern Japan. Univ. Mus. Univ. Tokyo Bull. 25.

Shpigel M., Fishelson L., 1989, Food habits and prey selection of three species of groupers from the genus Cephalopholis (Serranidae: Teleostei). Environ. Biol. Fish. 24, 67-73.

Stewart B.D., Jones G.P., 2001, Associations between the abundance of piscivorous fishes and their prey on coral reefs: implications for prey fish mortality. Mar. Biol. 138, 383-397.

St John J., 1999, Ontogenic changes in the diet of the coral reef grouper Plectropomus leopardus (Serranidae): patterns in taxa, size and habitat of prey. Mar. Ecol. Prog. Ser. 180, 233-246.

Stoner, A.W., 2004, Effects of environmental variables on fish feeding ecology: implications for the performance of baited fishing gear and stock assessment. J. Fish Biol. 65, 1445-1471.

Stergiou K.I., Karpouzi V.S., 2002, Feeding habits and trophic levels of Mediterranean fish. Rev. Fish Biol. Fish. 11, 217-254.

Temming, A., Götz S., Mergardt N., Ehrich S., 2004, Predation of whiting and haddock on sandeel: aggregative response, competition and diel periodicity. J. Fish Biol. 64, 1351-1372.

Thollot P., Kulbicki M., Harmelin-Vivien M., 1999, La structure trophique des peuplements des poissons de mangrove de Nouvelle Calédonie. C. R. Acad. Sci. Paris 322, 607-619.

Walker M.H., 1978, Food and feeding habits of Lethrinus chrysostomus Richardson (Pisces: Perciformes) and other Lethrinidae on the Great Barrier Reef. Aust. J. Mar. Freshw. Res. 29, 623-630.

Wantiez L., 1994, Réseaux trophiques de l'ichtyofaune des fonds meubles lagonaires de Nouvelle-Calédonie. C. R. Acad. Sci. Paris Sér. III Sci. Vie 317, 347-359.

Ward J.F., Austin R.M., Macdonald D.W., 2000, A simulation model of foraging behaviour and the effect of predation risk. J. Anim. Ecol. 69, 16-30.

Wolf N., 1987, Schooling tendency and foraging benefit in the ocean surgeonfish. Behav. Ecol. Sociobiol. 21, 59-63. 
Appendix I. Average volume of prey items in the stomach of fish. Only species with at least 5 full stomach analysed are given. Size (in cm). For more detailed information, please contact the first author directly. n: number of individuals examined; Shr.: shrimp; Oc.: other crustacean; Biv.: bivalve; Gas.: gasteropod; Om.: other molluscs; Ech.: echinoderm; Wo.: worm; Oth.: others.

\begin{tabular}{|c|c|c|c|c|c|c|c|c|c|c|c|c|}
\hline \multirow[t]{2}{*}{ Predator } & & & \multicolumn{10}{|c|}{ Prey } \\
\hline & $n$ & $\begin{array}{l}\text { Size } \\
\text { range }\end{array}$ & Fish & Crab & Shr. & Oc. & Biv. & Gas. & Om. & Ech. & Wo. & Oth. \\
\hline \multicolumn{13}{|l|}{ Dasyatidae } \\
\hline Dasyatis kuhlii & 6 & $21-42$ & & & 21 & 4 & 8 & & & & 63 & 4 \\
\hline \multicolumn{13}{|l|}{ Elopidae } \\
\hline Elops machnata & 11 & $20-83$ & 80 & 9 & 2 & & & & 9 & & & \\
\hline \multicolumn{13}{|l|}{ Megalopidae } \\
\hline Megalops cyprinoides & 10 & $19-47$ & 60 & 10 & 10 & 20 & & & & & & \\
\hline \multicolumn{13}{|l|}{ Albulidae } \\
\hline Albula sp. & 8 & $52-66$ & 13 & 40 & & 12 & 21 & & & & 14 & \\
\hline \multicolumn{13}{|l|}{ Synodontidae } \\
\hline Saurida gracilis & 9 & $14-18$ & 100 & & & & & & & & & \\
\hline Saurida undosquamis & 236 & $13-32$ & 92 & & 8 & & & & & & & \\
\hline Synodus dermatogenys & 9 & $11-17$ & 100 & & & & & & & & & \\
\hline \multicolumn{13}{|l|}{ Belonidae } \\
\hline Tylosurus crocodilus crocodilus & 13 & $43-88$ & 90 & 8 & & & 2 & & & & & \\
\hline \multicolumn{13}{|l|}{ Holocentridae } \\
\hline Neoniphon sammara & 6 & $11-19$ & 17 & 32 & 51 & & & & & & & \\
\hline Sargocentron rubrum & 85 & $8-23$ & 13 & 74 & 5 & 7 & & & 1 & & & \\
\hline Sargocentron spiniferum & 35 & $20-30$ & 7 & 60 & 11 & 9 & 3 & & 6 & & 3 & 1 \\
\hline \multicolumn{13}{|l|}{ Scorpaenidae } \\
\hline Dendrochirus brachypterus & 14 & $7-11$ & & 14 & 64 & 22 & & & & & & \\
\hline \multicolumn{13}{|l|}{ Platycephalidae } \\
\hline Onigocia macrolepis & 11 & $11-16$ & & 18 & 55 & 18 & & 9 & & & & \\
\hline Cymbacephalus beauforti & 5 & $30-52$ & 100 & & & & & & & & & \\
\hline \multicolumn{13}{|l|}{ Serranidae } \\
\hline Cephalopholis boenak & 5 & $11-21$ & 78 & & 20 & 2 & & & & & & \\
\hline Cephalopholis miniata & 12 & $27-42$ & 92 & & 8 & & & & & & & \\
\hline Epinephelus areolatus & 13 & $21-33$ & 38 & 46 & 12 & & 4 & & & & & \\
\hline Epinephelus coeruleopunctatus & 8 & $22-69$ & 20 & 60 & 20 & & & & & & & \\
\hline Epinephelus cyanopodus & 52 & $24-67$ & 56 & 24 & 5 & 8 & 3 & 1 & 3 & & & \\
\hline Epinephelus fasciatus & 27 & $12-33$ & 18 & 63 & 4 & 7 & & & & 8 & & \\
\hline Epinephelus macrospilos & 14 & $20-37$ & 28 & 56 & 7 & 7 & & & 1 & & 1 & \\
\hline Epinephelus maculatus & 121 & $19-52$ & 36 & 29 & 3 & 13 & 5 & & 11 & & 3 & \\
\hline Epinephelus malabaricus & 40 & $16-100$ & 24 & 62 & 8 & & & & 6 & & & \\
\hline Epinephelus merra & 42 & $11-24$ & 30 & 38 & 18 & 8 & 2 & & 2 & & 2 & \\
\hline Epinephelus polyphekadion & 60 & $22-59$ & 43 & 47 & 2 & 1 & & & 5 & 2 & & \\
\hline Epinephelus coioides & 8 & $29-96$ & 37 & 37 & 13 & & & & 13 & & & \\
\hline Plectropomus leopardus & 24 & $24-79$ & 88 & 4 & & 4 & & & 4 & & & \\
\hline Variola louti & 6 & $32-50$ & 83 & & & 17 & & & & & & \\
\hline \multicolumn{13}{|l|}{ Teraponidae } \\
\hline Terapon jarbua & 21 & $12-28$ & 55 & 30 & 5 & 5 & & & & & 5 & \\
\hline \multicolumn{13}{|l|}{ Priacanthidae } \\
\hline Priacanthus hamrur & 10 & $28-38$ & 10 & & 70 & 20 & & & & & & \\
\hline \multicolumn{13}{|l|}{ Apogonidae } \\
\hline Apogon hyalosoma & 8 & $11-13$ & 10 & 52 & 38 & & & & & & & \\
\hline Silaginidae & & & & & & & & & & & & \\
\hline Sillago spp. & 7 & $23-27$ & & 86 & & & & & & & 14 & \\
\hline Sillago sihama & 41 & $15-28$ & 3 & 47 & 5 & 3 & 7 & & & 2 & 33 & \\
\hline Echeneidae & & & & & & & & & & & & \\
\hline Echeneis naucrates & 14 & $52-78$ & 22 & & & 29 & 7 & & & 21 & & (1) 21 \\
\hline Carangidae & & & & & & & & & & & & \\
\hline Atule mate & 16 & $14-27$ & 75 & & & & & & & & & (2) 25 \\
\hline Carangoides spp. & 6 & $15-43$ & 67 & & 33 & & & & & & & \\
\hline Carangoides chrysophrys & 35 & $13-60$ & 62 & 6 & 19 & 10 & & & 3 & & & \\
\hline Carangoides ferdau & 12 & $29-56$ & 52 & 31 & & 17 & & & & & & \\
\hline
\end{tabular}


Appendix I. Continued.

\begin{tabular}{|c|c|c|c|c|c|c|c|c|c|c|c|c|}
\hline \multicolumn{3}{|c|}{ Predator } & \multicolumn{10}{|c|}{ Prey } \\
\hline & $n$ & $\begin{array}{l}\text { Size } \\
\text { range }\end{array}$ & Fish & Crab & Shr. & Oc. & Biv. & Gas. & Om. & Ech. & Wo. & Oth. \\
\hline Carangoides fulvoguttatus & 13 & $16-81$ & 88 & 4 & 8 & & & & & & & \\
\hline Carangoides orthogrammus & 16 & $29-62$ & 98 & 1 & 1 & & & & & & & \\
\hline Caranx ignobilis & 22 & $15-87$ & 65 & 20 & 13 & & & & 2 & & & \\
\hline Caranx papuensis & 36 & $10-65$ & 67 & 24 & 9 & & & & & & & \\
\hline Pseudocaranx dentex & 5 & $27-53$ & 60 & 40 & & & & & & & & \\
\hline Scomberoides tol & 29 & $12-23$ & 86 & & 10 & 4 & & & & & & \\
\hline \multicolumn{13}{|l|}{ Leiognathidae } \\
\hline Gazza minuta & 20 & $10-16$ & 99 & & 1 & & & & & & & \\
\hline \multicolumn{13}{|l|}{ Lutjanidae } \\
\hline Aprion virescens & 40 & $30-88$ & 46 & 7 & 7 & 14 & & & 16 & & 8 & 2 \\
\hline Lutjanus adetii & 69 & $19-51$ & 29 & 41 & 16 & 6 & 4 & & 1 & 2 & & 1 \\
\hline Lutjanus argentimaculatus & 139 & $15-53$ & 11 & 81 & 8 & & & & & & & \\
\hline Lutjanus bohar & 97 & $17-75$ & 61 & 9 & 1 & 4 & 2 & & 17 & & 3 & 3 \\
\hline Lutjanus fulviflammus & 108 & $7-33$ & 44 & 33 & 17 & 4 & & & & & 2 & \\
\hline Lutjanus fulvus & 91 & $8-28$ & 15 & 72 & 9 & 2 & & & & & 2 & \\
\hline Lutjanus gibbus & 199 & $17-39$ & 20 & 32 & 2 & 17 & 2 & 2 & 15 & 4 & 5 & 1 \\
\hline Lutjanus kasmira & 14 & $16-22$ & 13 & 43 & & 10 & & 9 & 25 & & & \\
\hline Lutjanus quinquelineatus & 149 & $13-23$ & 17 & 33 & 10 & 11 & 3 & 1 & 10 & 3 & 12 & \\
\hline Lutjanus russellii & 35 & $11-31$ & 57 & 13 & 30 & & & & & & & \\
\hline Lutjanus sebae & 18 & $25-77$ & 26 & 38 & 3 & 27 & & & 6 & & & \\
\hline Lutjanus vitta & 121 & $10-39$ & 47 & 21 & 18 & 10 & & & 2 & & 2 & \\
\hline Symphorus nematophorus & 15 & $45-92$ & 55 & 11 & 2 & 22 & & & 4 & 6 & & \\
\hline \multicolumn{13}{|l|}{ Gerreidae } \\
\hline Gerres filamentosus & 13 & $14-19$ & & 17 & 11 & 8 & 16 & 8 & & & 40 & \\
\hline \multicolumn{13}{|l|}{ Haemulidae } \\
\hline Diagramma pictum & 81 & $27-75$ & 8 & 12 & 3 & 10 & 21 & 3 & 23 & 9 & 11 & \\
\hline Plectorhinchus gibbosus & 6 & $21-35$ & 11 & 85 & 2 & & & & & & 2 & \\
\hline Plectorhinchus obscurus & 18 & $29-56$ & 4 & 54 & 19 & & 2 & & 3 & 7 & 3 & (1) 8 \\
\hline Plectorhinchus picus & 5 & $47-55$ & & 30 & & 20 & & 30 & 20 & & & \\
\hline Pomadasys argenteus & 161 & $13-42$ & 3 & 49 & 12 & 4 & 17 & & 1 & 3 & 10 & 1 \\
\hline \multicolumn{13}{|l|}{ Sparidae } \\
\hline Acanthopagrus berda & 97 & $12-36$ & & 79 & 1 & 1 & 4 & 9 & 3 & 1 & & 2 \\
\hline \multicolumn{13}{|l|}{ Lethrinidae } \\
\hline Gymnocranius spp. & 10 & $7-44$ & & 20 & & & 60 & & & 10 & 10 & \\
\hline Gymnocranius euanus & 197 & $20-49$ & 1 & 5 & & 2 & 24 & 6 & 28 & 22 & 10 & 2 \\
\hline Gymnocranius sp. & 62 & $20-49$ & & 3 & & 2 & 28 & 1 & 41 & 15 & 9 & 1 \\
\hline Gymnocranius grandoculis & 88 & $16-68$ & 7 & 8 & 1 & 4 & 17 & 4 & 29 & 9 & 12 & (3) 9 \\
\hline Lethrinus olivaceus & 77 & $23-73$ & 50 & 16 & 1 & 9 & 5 & 2 & 7 & 9 & 1 & \\
\hline Lethrinus harak & 35 & $13-32$ & 12 & 75 & & 6 & 4 & & & 3 & & \\
\hline Lethrinus lentjan & 86 & $15-40$ & 5 & 64 & 1 & 6 & 7 & 2 & 5 & 10 & & \\
\hline Lethrinus atkinsoni & 613 & $16-44$ & 14 & 15 & & 6 & 19 & 3 & 17 & 21 & 5 & \\
\hline Lethrinus miniatus & 5 & $38-86$ & 60 & 20 & & & & & & 20 & & \\
\hline Lethrinus nebulosus & 1023 & $11-69$ & 4 & 12 & 1 & 5 & 47 & 11 & 9 & 7 & 4 & \\
\hline Lethrinus genivittatus & 145 & $10-22$ & 13 & 22 & 9 & 9 & 9 & & 10 & 11 & 15 & 2 \\
\hline Lethrinus obsoletus & 7 & $22-30$ & & & & & 4 & & 53 & 12 & 31 & \\
\hline Lethrinus rubrioperculatus & 267 & $17-40$ & 23 & 30 & 2 & 26 & 1 & 1 & 11 & 2 & 3 & 1 \\
\hline Lethrinus variegatus & 23 & $12-29$ & 43 & 36 & 17 & & 1 & & 3 & & & \\
\hline Lethrinus xanthochilus & 25 & $27-63$ & 18 & 39 & 2 & 24 & & & 6 & 10 & 1 & \\
\hline Monotaxis grandoculis & 7 & $20-44$ & & 7 & & & 50 & & 14 & & 29 & \\
\hline \multicolumn{13}{|l|}{ Nemipteridae } \\
\hline Nemipterus furcosus & 413 & $12-26$ & 16 & 37 & 23 & 8 & 1 & & 5 & 3 & 7 & \\
\hline Scolopsis taenioptera & 167 & $10-21$ & & 6 & 6 & 4 & 17 & 2 & 7 & & 58 & \\
\hline \multicolumn{13}{|l|}{ Mullidae } \\
\hline Mulloidichthys flavolineatus & 22 & $11-18$ & 27 & 23 & 27 & 1 & & & & 17 & & 5 \\
\hline Parupeneus ciliatus & 5 & $18-24$ & & 72 & 28 & & & & & & & \\
\hline
\end{tabular}


Appendix I. Continued.

\begin{tabular}{|c|c|c|c|c|c|c|c|c|c|c|c|c|}
\hline \multicolumn{3}{|c|}{ Predator } & \multicolumn{10}{|c|}{ Prey } \\
\hline & $n$ & $\begin{array}{c}\text { Size } \\
\text { range }\end{array}$ & Fish & Crab & Shr. & Oc. & Biv. & Gas. & Om. & Ech. & Wo. & Oth. \\
\hline Parupeneus heptacanthus & 228 & $9-23$ & 6 & 15 & 28 & 12 & & & & & 39 & \\
\hline Upeneus moluccensis & 162 & $9-17$ & 17 & 20 & 36 & 5 & 3 & & 2 & 2 & 15 & \\
\hline Upeneus tragula & 112 & $8-24$ & 1 & 19 & 71 & 4 & 2 & & 2 & & 1 & \\
\hline Upeneus vittatus & 88 & $15-24$ & 3 & 22 & 26 & 8 & 22 & & 15 & 2 & 2 & \\
\hline Upeneus australiae & 46 & $9-18$ & & 2 & 47 & 9 & 5 & & & 2 & 35 & \\
\hline Upeneus guttatus & 6 & $10-14$ & & 16 & 17 & 67 & & & & & & \\
\hline \multicolumn{13}{|l|}{ Monodactylidae } \\
\hline Monodactylus argenteus & 5 & $5-19$ & 20 & 20 & 20 & & 10 & & & & 10 & ${ }^{(3)} 20$ \\
\hline \multicolumn{13}{|l|}{ Sphyraenidae } \\
\hline Sphyraena barracuda & 39 & $22-60$ & 99 & & 1 & & & & & & & \\
\hline Sphyraena forsteri & 17 & $28-60$ & 80 & & & 3 & 3 & & 14 & & & \\
\hline Sphyraena obtusata & 8 & $21-27$ & 100 & & & & & & & & & \\
\hline Sphyraena putnamie & 39 & $25-70$ & 95 & & & & & & 3 & & & 2 \\
\hline Sphyraena waitii & 6 & $20-25$ & 100 & & & & & & & & & \\
\hline \multicolumn{13}{|l|}{ Polynemidae } \\
\hline Polydactylus microstoma & 5 & $19-25$ & 51 & & 43 & 6 & & & & & & \\
\hline \multicolumn{13}{|l|}{ Labridae } \\
\hline Bodianus perditio & 177 & $25-73$ & 1 & 2 & & 5 & 18 & 10 & 58 & 6 & & \\
\hline Choerodon graphicus & 9 & $22-52$ & & & & & & 17 & 72 & 6 & & 5 \\
\hline \multicolumn{13}{|l|}{ Trichyuridae } \\
\hline Trichiurus lepturus & 6 & $58-96$ & 100 & & & & & & & & & \\
\hline \multicolumn{13}{|l|}{ Bothidae } \\
\hline Asterorhombus intermedius & 13 & $10-13$ & 92 & & 8 & & & & & & & \\
\hline Engyprosopon grandisquama & 9 & $8-11$ & & 3 & & 13 & & & & & 84 & \\
\hline Grammatobothus polyophthalmus & 13 & $15-21$ & 15 & 33 & 26 & 26 & & & & & & \\
\hline \multicolumn{13}{|l|}{ Balistidae } \\
\hline Abalistes stellaris & 28 & $26-52$ & 9 & 43 & 4 & 17 & 13 & & 8 & 4 & 2 & \\
\hline Pseudobalistes fuscus & 19 & $34-56$ & & 1 & & 6 & 24 & & 65 & 4 & & \\
\hline Sufflamen fraenatus & 17 & $22-36$ & & 21 & & 6 & & & 17 & 24 & & (3) 32 \\
\hline \multicolumn{13}{|l|}{ Monacanthidae } \\
\hline Pseudalutarius nasicornis & 16 & $11-13$ & & & & & & & 9 & & 1 & ${ }^{(4)} 90$ \\
\hline \multicolumn{13}{|l|}{ Tetraodontidae } \\
\hline Arothron hispidus & 6 & $31-46$ & & 3 & & & 47 & & 8 & & & (4) 42 \\
\hline Arothron manilensis & 8 & $11-33$ & & 16 & & 4 & 29 & 25 & 9 & & & ${ }^{(5)} 17$ \\
\hline Arothron stellatus & 10 & $39-75$ & & 25 & & & 28 & 17 & & 30 & & \\
\hline Lagocephalus sceleratus & 22 & $11-72$ & 15 & 49 & 8 & 9 & 1 & & 2 & 14 & & 2 \\
\hline
\end{tabular}

${ }^{(1)}$ Benthic algae, ${ }^{(2)}$ planktonic crustaceans, ${ }^{(3)}$ corals, ${ }^{(4)}$ sponges, ${ }^{(5)}$ octopi. 
Appendix II. Summary of the stomach content analysis by number of species (A) and by \% volume (B), according to fish size. Data by volume are averaged per species, not per individual. "Total" indicates the number of species involved.

A) By species: number of species per size class $(5 \mathrm{~cm})$ which had the item in their stomach.

\begin{tabular}{|c|c|c|c|c|c|c|c|c|c|c|c|c|c|c|c|c|}
\hline SIZE CLASS $(\mathrm{cm})$ & $5-$ & $10-$ & 15- & $20-$ & $25-$ & $30-$ & $35-$ & $40-$ & $45-$ & $50-$ & $60-$ & $70-$ & $80-$ & $90-$ & $>100$ & Total \\
\hline \multicolumn{17}{|l|}{ Crustaceans } \\
\hline Crabs & 4 & 26 & 42 & 49 & 40 & 33 & 28 & 26 & 20 & 28 & 17 & 9 & 3 & & & 115 \\
\hline Mantis shrimps & & 3 & 4 & 8 & 6 & 6 & 4 & 4 & 3 & 9 & 7 & 2 & 1 & & & 31 \\
\hline Planktonic crustaceans & & 1 & 2 & & & & & & & & & & & & & 2 \\
\hline Shrimps & 8 & 29 & 38 & 36 & 27 & 15 & 6 & 10 & 6 & 6 & 10 & 2 & 1 & & & 100 \\
\hline Other crustaceans & 4 & 19 & 25 & 22 & 14 & 21 & 16 & 11 & 10 & 11 & 7 & 3 & & & & 75 \\
\hline \multicolumn{17}{|l|}{ Echinoderms } \\
\hline Brittle stars & & 7 & 7 & 3 & 6 & 4 & 4 & 2 & & & & & & & & 19 \\
\hline Sand urchins & & 1 & 3 & 2 & 8 & 8 & 7 & 6 & 4 & 4 & 3 & 3 & 1 & & & 19 \\
\hline Other sea urchins & & 5 & 5 & 6 & 6 & 12 & 9 & 6 & 4 & 4 & 4 & & 1 & & & 29 \\
\hline Sea cucumbers & & & 2 & 1 & 7 & 5 & 3 & 2 & 1 & 2 & 2 & & & & & 14 \\
\hline Other echinoderms & & 1 & 2 & 3 & 4 & 4 & 3 & 2 & 2 & 2 & 1 & & & & & 14 \\
\hline \multicolumn{17}{|l|}{ Molluses } \\
\hline Bivalves & & 8 & 21 & 20 & 17 & 18 & 16 & 16 & 11 & 8 & 8 & 1 & & & & 60 \\
\hline Gastropods & & 6 & 4 & 10 & 11 & 9 & 8 & 7 & 7 & 8 & 3 & & & & & 31 \\
\hline Nudibranchs & & & 1 & 6 & 7 & 3 & 4 & 3 & 2 & 2 & 1 & & & & & 12 \\
\hline Squids/cuttlefish & & 2 & 6 & 3 & 6 & 5 & 4 & 3 & 5 & 7 & 6 & 1 & 1 & & & 27 \\
\hline Octopi & & 1 & 3 & 3 & 2 & 6 & & 1 & 1 & 4 & 4 & 4 & 2 & & & 22 \\
\hline Other mollusks & 3 & 8 & 16 & 14 & 14 & 20 & 16 & 13 & 12 & 9 & 7 & & & & & 54 \\
\hline \multicolumn{17}{|l|}{ Nekton } \\
\hline Finfish & 5 & 31 & 49 & 47 & 46 & 46 & 36 & 33 & 26 & 38 & 24 & 16 & 11 & 5 & 3 & 150 \\
\hline \multicolumn{17}{|l|}{ Others } \\
\hline Benthic algae & 1 & 3 & 1 & 2 & 6 & 1 & 2 & 3 & 1 & 1 & 1 & 1 & & & & 17 \\
\hline Corals & & 2 & 1 & 3 & 2 & 4 & 2 & 3 & 1 & 3 & 1 & 1 & & & & 14 \\
\hline Jelly fish & & & & 1 & 1 & 4 & 1 & 2 & & 2 & 1 & 1 & & & & 7 \\
\hline Sponges & & 1 & 1 & & 2 & 1 & & 1 & 2 & 2 & 1 & & & & & 9 \\
\hline Other organisms & & 2 & 2 & 1 & 2 & 1 & 3 & 1 & & 1 & & & & & & 10 \\
\hline Worms & 4 & 13 & 22 & 20 & 17 & 15 & 11 & 7 & 8 & 6 & 6 & 2 & & & & 57 \\
\hline TOTAL & 19 & 59 & 80 & 81 & 79 & 77 & 57 & 51 & 44 & 55 & 33 & 23 & 12 & 5 & 3 & 219 \\
\hline
\end{tabular}


Appendix II. Continued.

B) By volume.

\begin{tabular}{|c|c|c|c|c|c|c|c|c|c|c|c|c|c|c|c|c|}
\hline SIZE CLASS $(\mathrm{cm})$ & $5-$ & 10- & $15-$ & $20-$ & $25-$ & $30-$ & $35-$ & $40-$ & $45-$ & $50-$ & $60-$ & $70-$ & $80-$ & $90-$ & $>100$ & Total \\
\hline \multicolumn{17}{|l|}{ Crustaceans } \\
\hline All & 46.1 & 48.7 & 48.8 & 50.5 & 41.2 & 32.5 & 30.1 & 30 & 25.9 & 31.1 & 36.9 & 25.1 & 15.2 & & & \\
\hline Crabs & 10.2 & 18.2 & 25.2 & 33.3 & 25.6 & 18.8 & 22.4 & 22.2 & 17.7 & 23.4 & 19.2 & 16.8 & 11.7 & & & 19.2 \\
\hline Mantis shrimps & & 0.9 & 0.3 & 0.4 & 0.6 & 0.8 & 1.0 & 2.3 & 0.9 & 1.7 & 5.1 & 2.4 & 2.8 & & & 1.0 \\
\hline Planktonic crustaceans & & 1.7 & 0.6 & & & & & & & & & & & & & 0.1 \\
\hline Shrimps & 30 & 18.8 & 17.1 & 12.8 & 10.4 & 5.3 & 2.4 & 3.7 & 4.7 & 1.7 & 5.1 & 3.0 & 0.6 & & & 11.0 \\
\hline Other crustaceans & 5.9 & 9.1 & 5.6 & 3.9 & 4.6 & 7.6 & 4.3 & 1.8 & 2.7 & 4.3 & 7.4 & 2.8 & & & & 5.8 \\
\hline \multicolumn{17}{|l|}{ Echinoderms } \\
\hline All & & 3.8 & 1.4 & 1.7 & 3.2 & 4.1 & 5.5 & 2.3 & 2.7 & 3.0 & 3.9 & 1.4 & 4.9 & & & \\
\hline Brittle stars & & 3.1 & 0.7 & 0.2 & 0.5 & 0.1 & 0.2 & 0.1 & & & & & & & & 0.5 \\
\hline Sand urchins & & 0.3 & 0.3 & 0.9 & 1.4 & 1.7 & 1.9 & 1.3 & 0.7 & 0.8 & 1.7 & 1.4 & 0.7 & & & 0.8 \\
\hline Other sea urchins & & 0.3 & 0.4 & 0.4 & 0.9 & 1.6 & 3.3 & 0.5 & 1.7 & 2.0 & 1.9 & & 4.2 & & & 0.8 \\
\hline Sea cucumbers & & & 0.08 & 0.01 & 0.19 & 0.33 & 0.06 & 0.09 & 0.02 & 0.15 & 0.27 & & & & & 0.1 \\
\hline Other echinoderms & & 0.04 & 0.1 & 0.1 & 0.3 & 0.4 & 0.1 & 0.3 & 0.3 & 0.2 & 0.1 & & & & & 0.2 \\
\hline \multicolumn{17}{|l|}{ Molluscs } \\
\hline All & 8.7 & 4.7 & 10.3 & 12.7 & 12.7 & 19.8 & 19.4 & 19.3 & 28.1 & 13.8 & 7.0 & 8.1 & 4.0 & & & \\
\hline Bivalves & & 1.9 & 5.0 & 5.6 & 5.7 & 8.1 & 7.2 & 8.8 & 9.9 & 4.7 & 2.3 & 4.4 & & & & 4.3 \\
\hline Gastropods & & 1.58 & 1.64 & 1.8 & 2.54 & 1.57 & 2.38 & 0.81 & 6.32 & 4.57 & 1.28 & & & & & 2.0 \\
\hline Nudibranchs & & & 0 & 0.6 & 0.7 & 0.1 & 0.8 & 0.5 & 0.4 & 0.1 & 0.5 & & & & & 0.3 \\
\hline Octopi & & 0.04 & 0.03 & 0.18 & 0.31 & 1.59 & & 0.28 & 0.23 & 0.45 & 0.31 & 3.78 & 4.03 & & & 0.5 \\
\hline Squids/cuttlefish & & 0.18 & 0.29 & 0.16 & 1.54 & 0.33 & 0.42 & 1.08 & 1 & 3.43 & 2.59 & 0.04 & 2.08 & & & 0.9 \\
\hline Other mollusks & 8.7 & 1.1 & 3.7 & 4.4 & 3.5 & 8.5 & 9.1 & 8.9 & 11.3 & 4.0 & 2.7 & & & & & 5.0 \\
\hline \multicolumn{17}{|l|}{ Nekton } \\
\hline Finfish & 23.9 & 29.1 & 30 & 30.1 & 33.4 & 37.5 & 38 & 39.9 & 36.4 & 46.5 & 47.1 & 56.7 & 73.8 & 100 & 100 & 38.1 \\
\hline \multicolumn{17}{|l|}{ Others } \\
\hline All & 5.3 & 4.2 & 1.3 & 0.8 & 3.9 & 1.8 & 2.9 & 2.6 & 4.6 & 1.1 & 0.6 & 7.8 & & & & \\
\hline Benthic algae & 5.3 & 2.1 & 0.01 & 0.04 & 0.5 & 0.2 & 2.6 & 1.0 & 0.01 & 0 & 0.3 & 3.3 & & & & 1.3 \\
\hline Corals & & 0.8 & 0.01 & 0.8 & 0.9 & 1.5 & 0.1 & 0.3 & 0 & 0.9 & 0.2 & 4.4 & & & & 0.6 \\
\hline Jelly fish & & & & 0.01 & 0 & 0.1 & 0.08 & 0.29 & & 0.07 & 0.23 & 0.14 & & & & 0.03 \\
\hline Sponges & & 1.2 & 0.6 & & 1.3 & 0.01 & & 1.1 & 4.6 & 0.06 & 0.03 & & & & & 1.6 \\
\hline Other organisms & & 0.04 & 0.63 & 0.01 & 1.27 & 0 & 0.08 & 0.08 & & 0 & & & & & & 0.5 \\
\hline Worms & 16.1 & 9.4 & 7.9 & 4.1 & 4.1 & 4.0 & 3.7 & 4.8 & 1.2 & 1.0 & 1.9 & 1.0 & & & & 5.6 \\
\hline
\end{tabular}

